Article

\title{
A Methodology for Comparing the Surface Urban Heat Island in Selected Urban Agglomerations Around the World from Sentinel-3 SLSTR Data
}

\author{
José Antonio Sobrino ${ }^{1, *(D)}$ and Itziar Irakulis ${ }^{2}$ (D) \\ 1 Global Change Unit (UCG), Image Processing Laboratory (IPL), University of Valencia (UVEG), \\ 46980 Paterna, Spain \\ 2 Land and Atmosphere Remote Sensing group (LARS), Centro de Tecnologías Físicas, Universitat Politècnica \\ de València (UPV), 46022 Valencia, Spain; iiraloi@doctor.upv.es \\ * Correspondence: sobrino@uv.es
}

Received: 17 May 2020; Accepted: 24 June 2020; Published: 25 June 2020

\begin{abstract}
Retrieval of land surface temperature (LST) from satellite data allows to estimate the surface urban heat island (SUHI) as the difference between the LST obtained in the urban area and the LST of its surroundings. However, this definition depends on the selection of the urban and surroundings references, which translates into greater difficulty in comparing SUHI values in different urban agglomerations across the world. In order to avoid this problem, a methodology is proposed that allows reliable quantification of the SUHI. The urban reference is obtained from the European Space Agency Climate Change Initiative Land Cover and three surroundings references are considered; that is, the urban adjacent $(\mathrm{Su})$, the future adjacent $(\mathrm{Sf})$, and the peri-urban $(\mathrm{Sp})$, which are obtained from mathematical expressions that depend exclusively on the urban area. In addition, two formulations of SUHI are considered: $\mathrm{SUHI}_{\mathrm{MAX}}$ and $\mathrm{SUHI}_{\mathrm{MEAN}}$, which evaluate the maximum and average SUHI of the urban area for each of the three surrounding references. As the urban population growth phenomenon is a world-scale problem, this methodology has been applied to 71 urban agglomerations around the world using LST data obtained from the sea and land surface temperature radiometer (SLSTR) on board Sentinel-3A. The results show average values of SUHI MEAN of $(1.8 \pm 0.9){ }^{\circ} \mathrm{C},(2.6 \pm 1.3){ }^{\circ} \mathrm{C}$, and $(3.1 \pm 1.7){ }^{\circ} \mathrm{C}$ for Su, Sf, and Sp, respectively, and an average difference between $\mathrm{SUHI}_{\mathrm{MAX}}$ and $\mathrm{SUHI}_{\mathrm{MEAN}}$ of $(3.1 \pm 1.1){ }^{\circ} \mathrm{C}$. To complete the study, two additional indices have been considered: the Urban Thermal Field Variation Index (UFTVI) and the Discomfort Index (DI), which proved to be essential for understanding the SUHI phenomenon and its consequences on the quality of life of the inhabitants.
\end{abstract}

Keywords: thermal remote sensing; land surface temperature; urban heat island; SLSTR; Sentinel-3

\section{Introduction}

By 2050, the world's population is estimated to increase to nine billion, 70\% of whom will live in urban areas [1]. The rapid increase of these areas without adequate prior planning is an increasingly worrying problem that seriously threatens the environment and the health and well-being of the population [2].

One of the most problematic consequences of rapid urbanization is the increase of the urban heat island (UHI) [3,4], which is defined as the difference between the air temperature (AT) within the urban area and the AT of its surroundings [5]. Generally, the temperature in urban areas is higher than in rural areas, especially at night [5]. This phenomenon, which will be reinforced by the effects of climate change, not only affects people psychologically and physiologically, but also controls daily behaviours and economic activities [6] and can lead to a drastic increase in morbidity and mortality [7], increased 
energy consumption [8], and even violent behaviours [9] within urban areas [10]. UHI was shown to also have a positive effect on heating-dominated buildings owing to the lower heating demands during winter [11]. When the UHI is monitored with remote sensing data, we have to talk about surface urban heat island (SUHI), as the parameter studied is no longer AT, but the land surface temperature (LST) [12].

Many authors have written on obtaining LST and urban heat islands on spatial, spectral, and temporal scales [3,4,13-24], in addition to examining satellite sensors that may be more or less suitable for SUHI detection and calculation [25]. Other authors have documented the importance of different satellite images in detecting the relationship between LST and land use change [26,27], but most of the studies carried out to date focus on a single city or urban agglomeration where the definition of rural and urban areas is adapted to each study case [10], which complicates the comparison between cities in different parts of the world. On the other hand, there is no concrete methodology to define the non-urban area. Proper selection of this area is crucial to make a correct estimation of the SUHI. If we consider areas too close to the city, the effect can be underestimated, owing to the human activity that persists outside the urban core, and in highly urbanized metropolitan areas, it is likely that external reference areas are influenced by the SUHI of nearby cities [28]; in addition, too external areas may suppose too extreme a change of scenario to use as a reference.

In this paper, we propose a new methodology to calculate and compare SUHI values of urban agglomerations around the world. SUHI will be calculated for three surrounding areas using LST acquired during the night-time according to the recommendations given by [12]. The proposed methodology is applied to 71 selected urban agglomerations around the world. The LST product used was the provided by the European Space Agency (ESA) from the land and sea surface temperature radiometer (SLSRT) aboard the Sentinel-3A (SLSTR Level-2 LST) [29] (for more information, visit the site https://earth.esa.int/web/sentinel/technical-guides/sentinel-3-slstr/level-2/lst-processing). Finally, to complement SUHI analysis, two additional indices have been considered, the Urban Thermal Field Variance Index (UTFVI), which quantifies the SUHI at the district level [6,18,30], and the Discomfort Index (DI), which estimates the impact of temperature on human health [31].

\section{Methodology}

\subsection{SUHI Selection of the Urban and Surrounding References}

The main objective of this work is to present a methodology that allows the analysis and comparison of SUHI in urban agglomerations around the world. For this purpose, night-time LST obtained from satellite data has been used [12] to estimate $\mathrm{SUHI}_{\mathrm{MAX}}$ and $\mathrm{SUHI}_{\mathrm{MEAN}}$, which are defined as the thermal differences between the maximum and average LST of the urban area and the LST of its surroundings, respectively, according to

$$
\begin{aligned}
\mathrm{SUHI}_{\text {MAX }} & =\mathrm{LST}_{\mathrm{URB}-\mathrm{MAX}}-\mathrm{LST}_{\mathrm{SUR}} \\
\mathrm{SUHI}_{\text {MEAN }} & =\mathrm{LST}_{\mathrm{URB}-\mathrm{MEAN}}-\mathrm{LST}_{\text {SUR }}
\end{aligned}
$$

where LST $_{\text {URB-MAX }}$ is the maximum LST of the urban area (hottest pixel), LST $_{\text {URB-MEAN }}$ is the average temperature of the pixels that define the urban area, and LST $_{\text {SUR }}$ is the average temperature of the pixels that compose the surrounding area.

The main problem in estimating $\mathrm{SUHI}_{\mathrm{MAX}}$ and $\mathrm{SUHI}_{\text {MEAN }}$ is the difficulty in identifying urban and surrounding references. There is no clear definition in the literature of how to select these areas [32], which makes it extremely difficult to compare SUHI between different urban agglomerations. To address this problem, we propose the following approach:

\section{(a) Urban:}

To define the urban reference, a land cover map with explicit representation of urban areas is the most operational solution. In our case, among the large number of free land cover products available today, we use the global land cover map produced by the European Space Agency (ESA) Climate Change 
Initiative (CCI) [33] (for more information, visit the website https://maps.elie.ucl.ac.be/CCI/viewer/), where the urban reference is obtained from those classified as "urban areas". From this class, a polygon is generated that is identified with the area of the urban agglomeration selected (A).

(b) Surroundings:

As for the surrounding, three different reference areas were defined, the urban adjacent $\left(\mathrm{S}_{\mathrm{U}}\right)$, the future urban adjacent $\left(\mathrm{S}_{\mathrm{f}}\right)$, and the peri-urban $\left(\mathrm{S}_{\mathrm{P}}\right)$. The width $\left(\mathrm{W}_{\mathrm{U}}, \mathrm{W}_{\mathrm{f}}\right.$, and $\left.\mathrm{W}_{\mathrm{P}}\right)$ of the buffer for each surrounding is calculated as follows:

$$
\begin{gathered}
\mathrm{W}_{\mathrm{U}}=0.25 \mathrm{~A}^{1 / 2} \\
\mathrm{~W}_{\mathrm{f}}=0.25 \mathrm{~A}_{\mathrm{Wu}}{ }^{\frac{1}{2}} \\
\mathrm{~W}_{\mathrm{P}}=1.5 \mathrm{~A}^{1 / 2}-\mathrm{W}_{\mathrm{f}}-\mathrm{W}_{\mathrm{U}}
\end{gathered}
$$

where $\mathrm{Awu}$ is the sum of $\mathrm{A}$ and $\mathrm{Su}$ areas (see Figure 1). Similar expressions for $\mathrm{Wu}$ and $\mathrm{Wp}$ can be found in [34] and [35], respectively, while $W_{\mathrm{f}}$ is introduced in this paper assuming future expansion of the urban area to include the urban adjacent surrounding Su. With this approach, the extent of the surrounding areas is clearly defined and depends only on A (the area of the urban agglomeration). As an example, Figure 2 shows the application of the methodology to the Paris urban agglomeration.

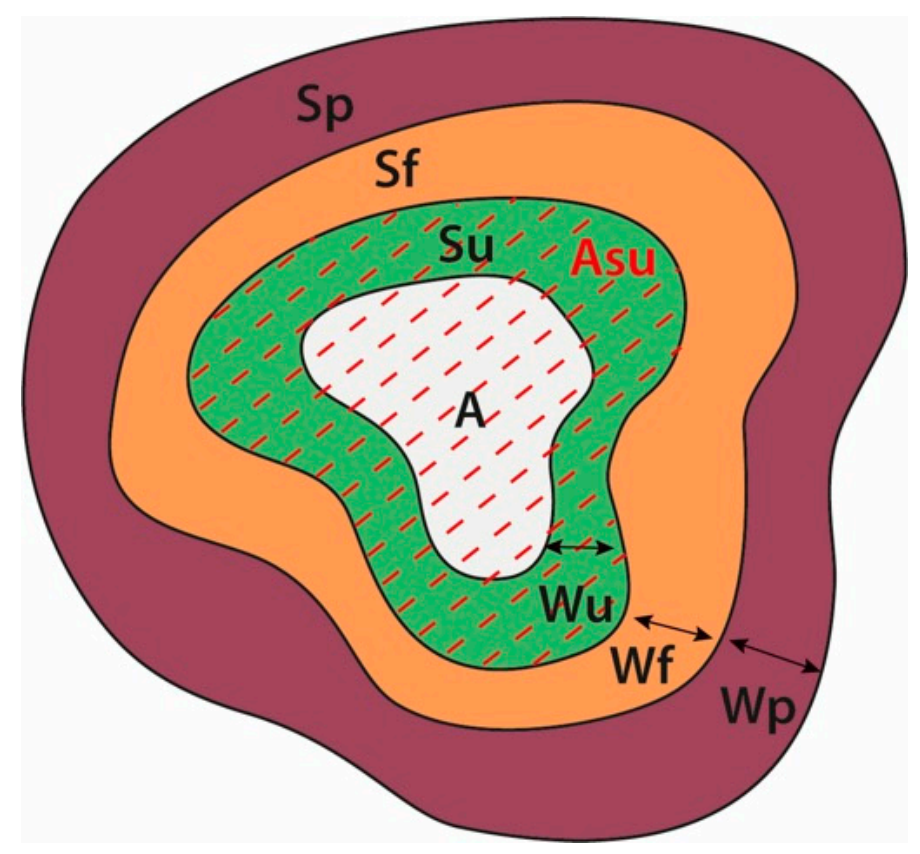

Figure 1. Boundaries definition concept. 


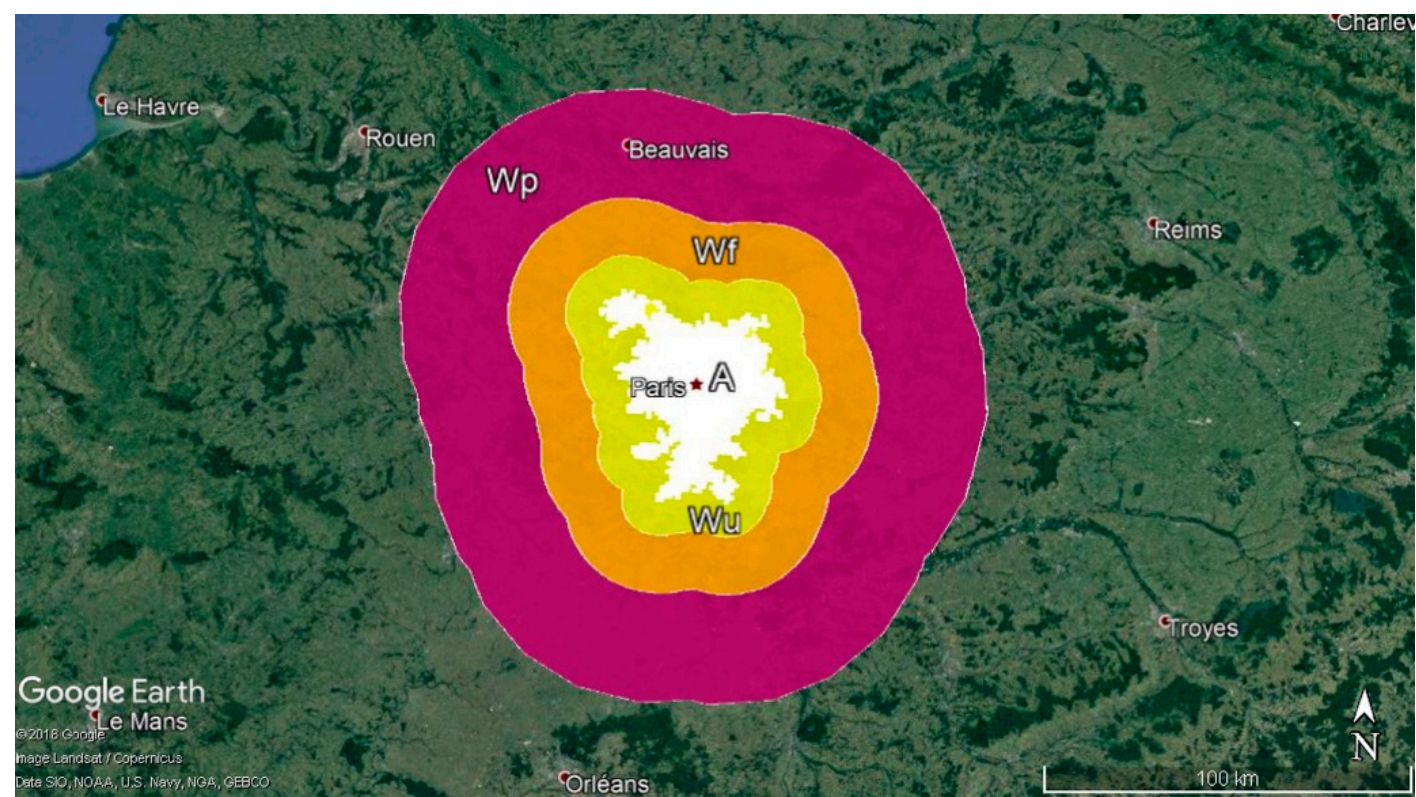

Figure 2. Surrounding areas of the Paris agglomeration. The white colour is the urban agglomeration polygon generated from the land cover map produced by European Space Agency (ESA) Climate Change Initiative (CCI) [33], whose value is $1457 \mathrm{~km}^{2}$. The yellow, orange, and burgundy colours are those of the surrounding areas $\mathrm{Su}, \mathrm{Sf}$, and $\mathrm{Sp}$, respectively, which are obtained from QGIS with the buffer tool $\left(\mathrm{W}_{\mathrm{U}}=9.5 \mathrm{~km}, \mathrm{~W}_{\mathrm{f}}=15.7 \mathrm{~km}\right.$, and $\left.\mathrm{W}_{\mathrm{P}}=32.1 \mathrm{~km}\right)$.

\subsection{UTFVI and DI Indices}

To complement the analysis of SUHI, two additional indices were considered. That is, the Urban Thermal Field Variance Index (UTFVI) [18,31] and the Discomfort Index (DI) [36]. The UTFVI is the most widely used index for the ecological evaluation of urban environment owing to its direct relation to LST and considers the thermal impact of the different sub-areas (district level) in the urban agglomeration area (A), according to

$$
\mathrm{UFTVI}=1-\left(\mathrm{LST}_{\mathrm{URB}-\mathrm{MEAN}} / \mathrm{LST}_{\mathrm{URB}-\mathrm{PIXEL}}\right)
$$

where LST $_{\text {URB-PIXEL }}$ is the LST in K, obtained from satellite data, of a given pixel of A and LST $_{\text {URB-MEAN }}$

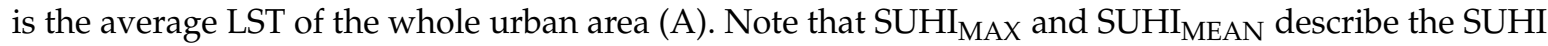
between the whole urban area and the surroundings, while UFTVI is used for evaluating the effect for each pixel located within the urban area with respect to the whole urban area. UTFVI is divided into six levels by six specific ecological evaluation indices. The thresholds at the six UFTVI levels are shown in Table 1, from no SUHI (excellent) if LST URB-PIXEL $_{\text {UST }}$ LSTRB-MEAN $_{\text {UR strongest (worst) with }}$ UFTVI $>0.02$, a situation that occurs when the value of LST $_{\text {URB-PIXEL }}$ is several degrees higher than

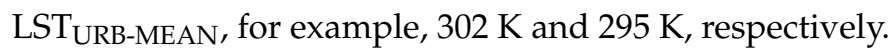

Table 1. Threshold values of Urban Thermal Field Variance Index (UTFVI) and ecological evaluation index [18].

\begin{tabular}{ccc}
\hline Urban Thermal Field Variation Index & Urban Heat Island Phenomenon & Ecological Evaluation Index \\
\hline$<0$ & None & Excellent \\
$0-0.005$ & Weak & Good \\
$0.005-0.010$ & Middle & Normal \\
$0.010-0.015$ & Strong & Bad \\
$0.015-0.020$ & Stronger & Worse \\
$>0.020$ & Strongest & Worst \\
\hline
\end{tabular}


It is well known that one of the consequences of SUHI is the influence on human health. The Discomfort Index (DI), also known as the Thom's discomfort index [37], is a measure of the reaction of the human body to a combination of heat and humidity. DI can be estimated according to Sobrino et al. [5] at night-time from satellite measurements according to

$$
\mathrm{DI}=\mathrm{LST}-(0.55-0.055 \mathrm{RH})(\mathrm{LST}-14.5)
$$

where LST is the land surface temperature in $\circ \mathrm{C}$, obtained from satellite data, for a given pixel of $\mathrm{A}$ and RH is the relative humidity in \%. RH can be obtained from in situ or satellite data. Our objective is to propose an operational methodology and, for this purpose, RH is obtained from the atmospheric infrared sounder (AIRS), L3 surface relative humidity product on board NASA's AQUA satellite [38]. DI is divided into ten categories, which are shown in Table 2.

Table 2. Threshold values of the Discomfort Index (DI) categories [36].

\begin{tabular}{cc}
\hline DI Categories & DI temperature $\left({ }^{\circ} \mathbf{C}\right)$ \\
\hline Hyperglacial & $<-40$ \\
Glacial & -39.9 to -20 \\
Extremely cold & -19.9 to -10 \\
Very cold & -9.9 to -1.8 \\
Cold & -1.7 to +12.9 \\
Cool & +13 to +14.9 \\
Comfortable & +15 to +19.9 \\
Hot & +20 to +26.4 \\
Very hot & +26.5 to +29.9 \\
Torrid & $>+30$ \\
\hline
\end{tabular}

\subsection{Criteria for Urban Agglomerations Selection}

In order to apply the methodology developed, 71 urban agglomerations were selected around the world: 7 in Africa, 19 in America, 24 in Asia, 18 in Europe, and 3 in Oceania (more information on the characteristics of the selected agglomerations can be found in Appendix A). The criteria used for selection (see Figure 3a-c) were as follows

(a) urban agglomeration areas, which cover the globe as extensively and widely as possible at different latitudes and longitudes, in different climatic zones and with different population and density of habitants, giving priority to those that are experiencing a large increase in population $[39,40]$ or are considered particularly vulnerable to climate change [41];

(b) urban areas at different altitudes (e.g., from Perth at $0 \mathrm{~m}$ above sea level to Lhasa at $3650 \mathrm{~m}$ );

(c) coastal and inland agglomerations (e.g., Rio de Janeiro, Moscow);

(d) urban agglomerations with high levels of $\mathrm{NO}_{2}$ [42] and night-time light pollution (e.g., Shanghai, New York);

(e) urban agglomerations with an area greater than $50 \mathrm{~km}^{2}$ in order to have a number of pixels representative at the spatial resolution of the satellite. 


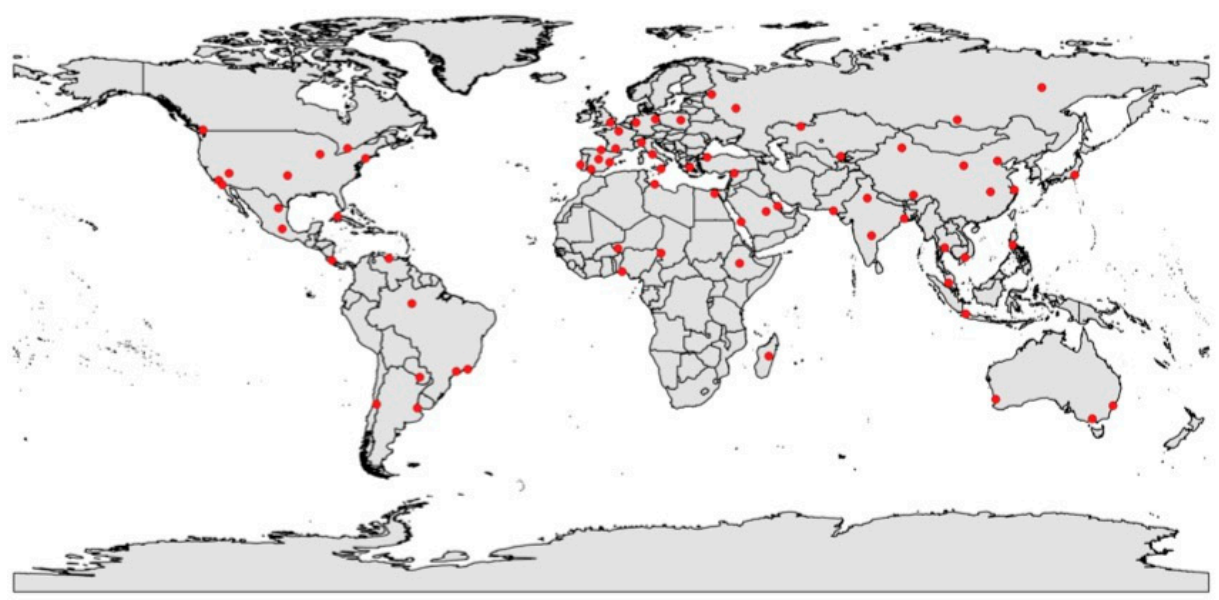

(a)

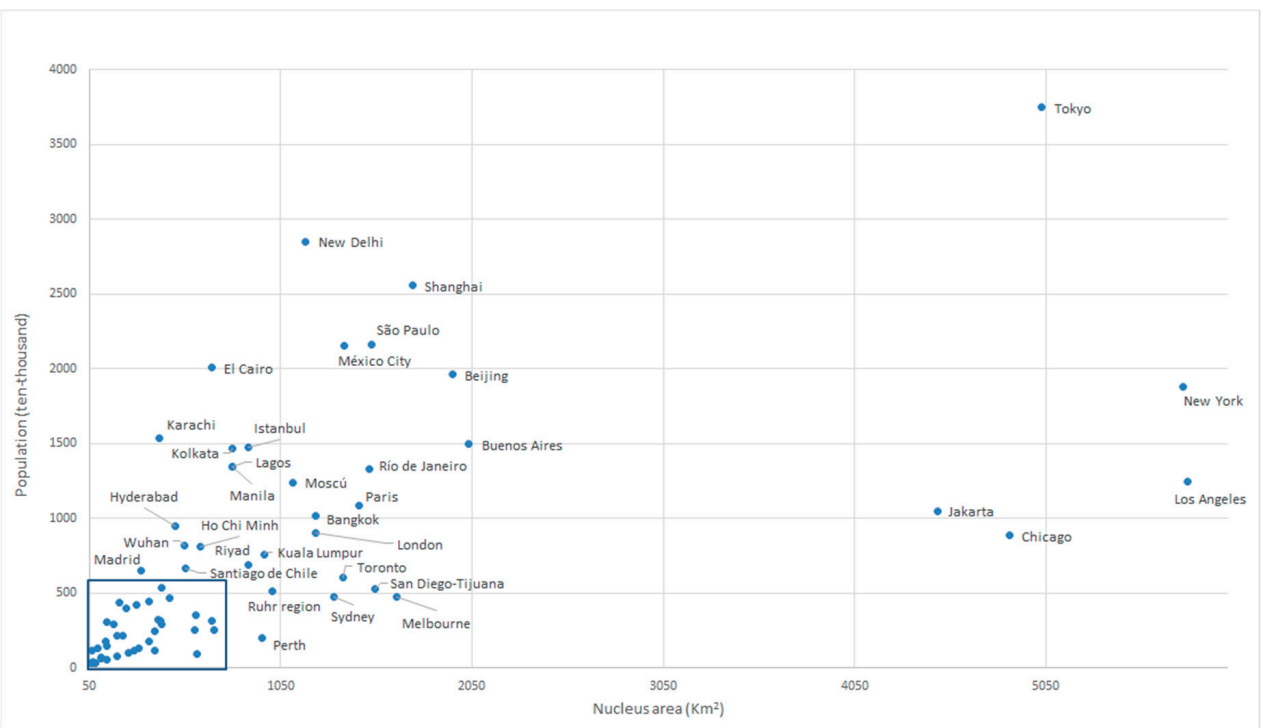

(b)

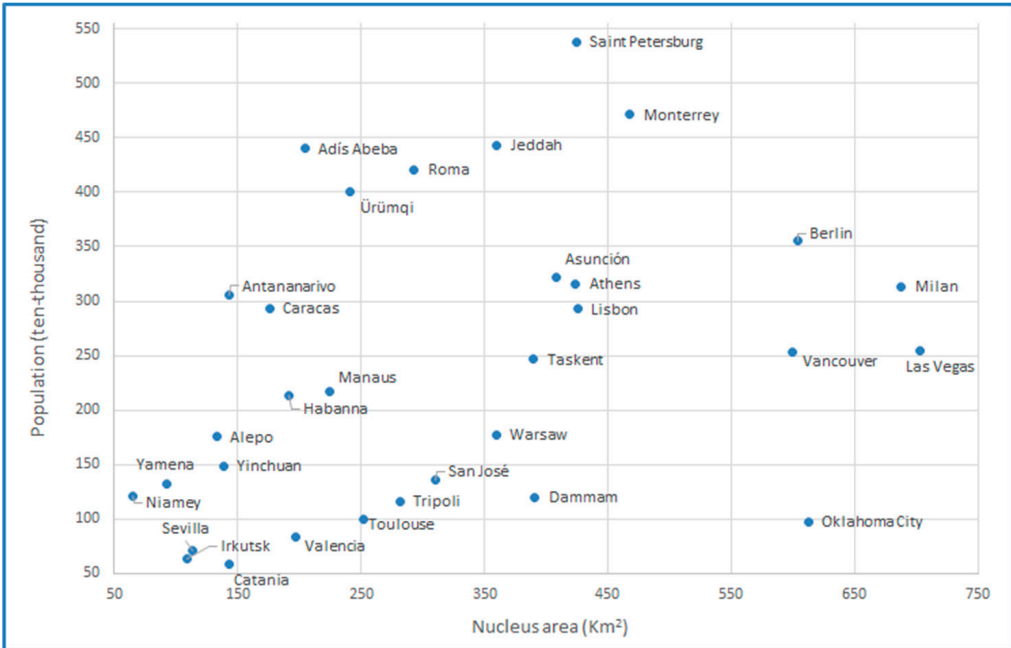

(c)

Figure 3. (a) Geographical location of the 71 selected urban agglomerations (red points), (b) population (in thousands of inhabitants) versus urban extension $\left(\mathrm{km}^{2}\right)$, and (c) detail for agglomerations with less than 5550 thousand inhabitants and $750 \mathrm{~km}^{2}$ of surface. 


\subsection{Satellite Data}

So far, the most used satellites for SUHI estimation have been TERRA, AQUA, and Landsat [11], with few studies using data from the ESA's Sentinel 3 satellites owing to the short period of operation. In this paper, SUHI is analysed using the LST product obtained from the SLSTR sensor onboard Sentinel-3A (Level-2 LST) [29] during the period June 2018 to May 2019. Night images were selected following Sobrino et al. [5], when the SUHI effect is most notable. For each urban agglomeration, the month with the warmest temperature records was searched, and for that month, a warm and clear night.

Level-2 LST products have been validated against in situ observations from twelve "gold standard" stations spread thoughout the Earth that are installed with well-calibrated instrumentation: seven from the Surface Radiation Budget Network (SURFRAD) in Bondville, Illinois; Desert Rock, Nevada; Fort Peck, Montana; Goodwin Creek, Mississippi; Penn State University, Pennsylvania; Sioux Fall, South Dakota; Table Mountain, and Colorado; two from the Atmospheric Radiation Measurement (ARM) network in Southern Great Plains, Oklahoma; Barrow, and Alaska; and three from the U.S. Clima Reference Network (USCRN) in Williams, Arizona; Des Moines, Iowa; Manhatten, and Kansas. The average absolute accuracy is within the $1 \mathrm{~K}$ requirement (better than $1 \mathrm{~K}$ ) [43].

\section{Results and Discussion}

In this section, values of SUHI, UTFVI, and DI in 71 urban agglomerations around the world are given. It is important to note that whether a given agglomeration has high or low values of SUHI, or can be classified according to the values of UFTVI and $\mathrm{Di}$, should be interpreted as these are the results for the day and time of the selected Sentinel 3A image (more information, including the numerical values of the indices and the Level-2 LST for each agglomeration, can be found in Appendix A).

We also want to point out that the main objective of the present work is to propose an operational methodology that allows a systematic and effective assessment of SUHI, UTFVI, and DI in order to detect warning situations and identify the vulnerabilities of the urban area. This is particularly necessary in the current context of global warming, but even more so if we consider future scenarios, for example, Sobrino et al. [44] shows a linear warming trend of the surface temperature of the planet of $0.18 \mathrm{~K}$ per decade. In that sense, the inhabitants of the urban area, especially those who live or develop their activities in urban districts with high UTFVI values, are already intensely suffering the effects of the increase in temperature.

\subsection{SUHI}

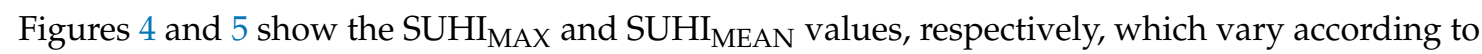
the agglomeration and the surrounding area considered. The proposed methodology has the potential to reflect the differences in a quantitative way. For example, the European agglomerations show less dispersion than the American and Asian agglomerations, among which there were those that present greater differences with respect to the selected surrounding.

In general, the highest differences are for the peri-urban areas $\left(S_{p}\right)$, and the smallest are for the urban adjacent (Su). We only identified three cases (San Diego-Tijuana, Los Angeles, and Taskent) that show a different pattern to the other 68 cities with greater temperature differences in the adjacent urban surroundings (Su) and smaller in Sf and Sp. In the case of San Diego-Tijuana and Los Angeles, the temperature of the most remote areas is higher owing to the proximity of desert and other urban agglomerations that emit heat. Taskent, on the other hand, has an adjacent urban area of crops and irrigated land that cools the surface, while the farthest areas are covered with dry vegetation or bare soil. Other particular cases are agglomerations that show similar SUHI values for Su, Sf, and Sp (e.g., Dammam, Calcutta, Shanghai, or Athens). In most cases, this corresponds to urban areas whose surroundings present similar characteristics to the area close to the urban nucleus. Characteristics that are not very common in the rest of the selected agglomerations. In the case of Lhasa, the values 
for Sf and Sp are much higher than for Su. This is because the city of Lhasa is built in the valley of the Brahmaputra river, surrounded by the Himalayan mountains that take altitudes immediately higher than those of the city in very short distances, which contributes to the maintenance of higher temperatures in the urban area. In addition, the dams built in the river regulate the temperature of the city holding part of the heat accumulated during the day. In some cases, there is a big difference in LST in the hottest area within the urban area compared with the peri-urban area (Sp). Figure 4 (blue column) shows values above $8{ }^{\circ} \mathrm{C}$ in Vancouver, New York, Tokyo, Lhasa, Ürümqi, Las Vegas, Ciudad de Mexico, Rio de Janeiro, Jakarta, Buenos Aires, San José, and Moscow.

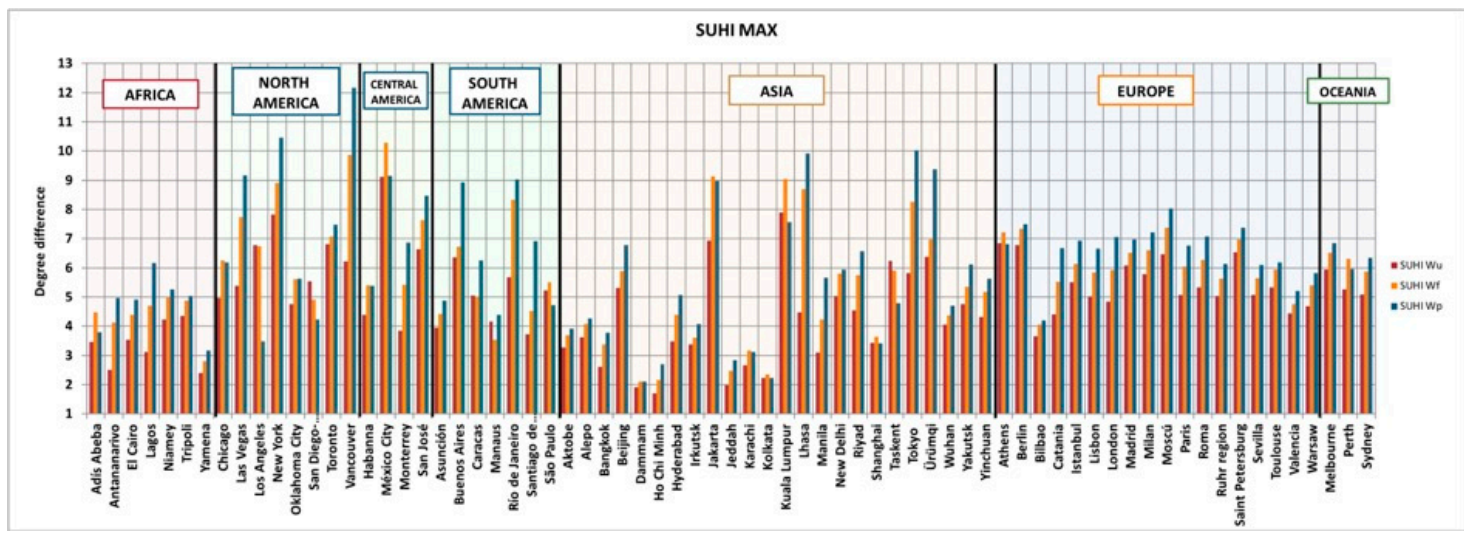

Figure 4. Surface urban heat island (SUHI) MAX values (height of the column) in ${ }^{\circ} \mathrm{C}$ for the adjacent urban (red), the future adjacent urban (orange), and the peri-urban (blue) surroundings of the 71 agglomerations selected.

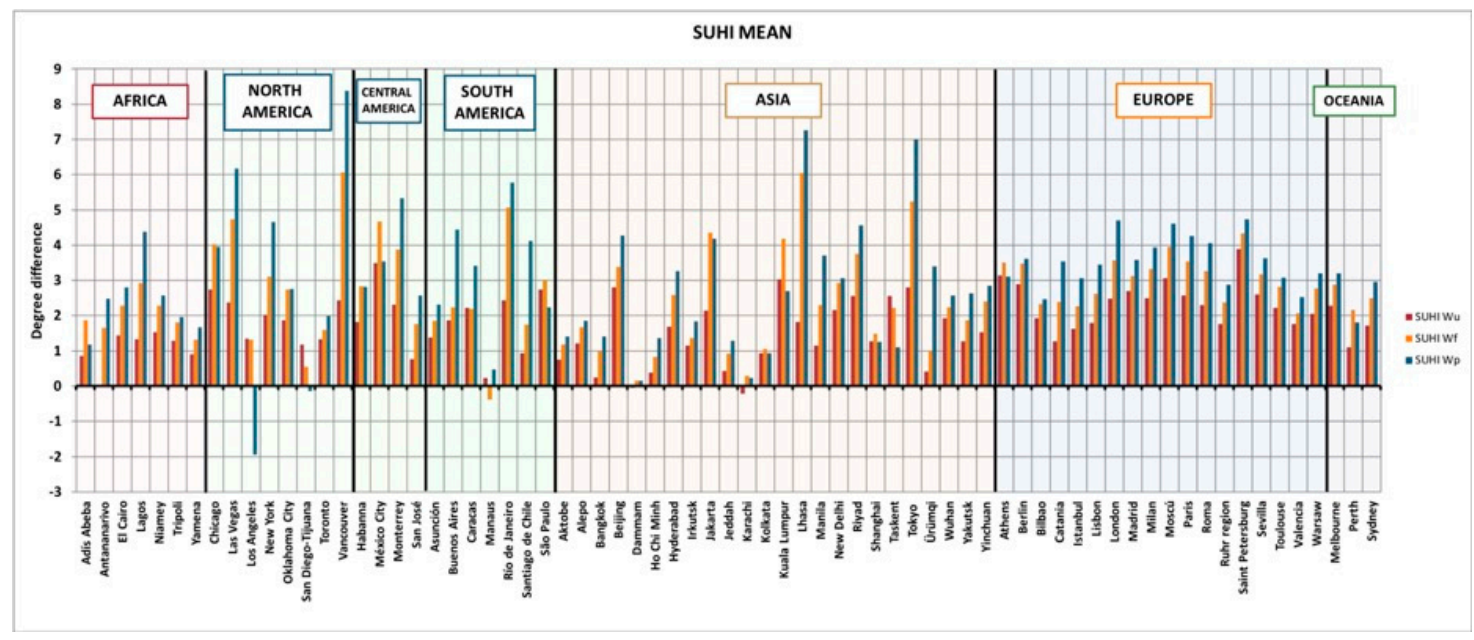

Figure 5. SUHI MEAN values (height of the column) in ${ }^{\circ} \mathrm{C}$ for the adjacent urban (red), the future adjacent urban (orange), and the peri-urban (blue) surroundings of the 71 urban agglomerations selected.

A relevant aspect to highlight is that the average difference between $\mathrm{SUHI}_{\mathrm{MAX}}$ and $\mathrm{SUHI}_{\mathrm{MEAN}}$ for all cases is $(3.1 \pm 1.1){ }^{0} \mathrm{C}$ (see numerical values in Table A2 of Appendix A). This implies that, on average for the agglomerations selected, the inhabitants of the urban zone where the maximum temperature occurs experience up to 3.1 degrees higher LST than the rest of the inhabitants of the urban agglomerations. Note that a difference of zero between $\mathrm{SUHI}_{\mathrm{MAX}}$ and $\mathrm{SUHI}_{\text {MEAN }}$ would imply a value of UFTVI lower than 0 (i.e., an excellent ecological evaluation index, see Table 1).

As a complement to Figure 5, Table 3 shows the SUHI MEAN values for the three surrounding areas $(\mathrm{Su}, \mathrm{Sf}$, and $\mathrm{Sp}$ ) ordered according to the following criteria: by continent, for populations above 20 million inhabitants, with an urban area higher than $1000 \mathrm{~km}^{2}$, at a minimum distance of $1000 \mathrm{~km}$ 
from the coast, at an altitude higher than $1 \mathrm{~km}$ above sea level, by climate classification according to the five Köppen vegetation groups [45] and including the 71 agglomerations.

Table 3. Values of surface urban heat island (SUHI) MEAN in $\left({ }^{\circ} \mathrm{C}\right)$ for the urban adjacent $(\mathrm{Su})$, the future adjacent (Sf), and the periurban (Sp) considering different criteria.

\begin{tabular}{cccc}
\hline Criteria & SUHI $_{\text {MEAN }}(\mathbf{S u})\left({ }^{\circ} \mathbf{C}\right)$ & SUHI $_{\text {MEAN }}(\mathbf{S f})\left({ }^{\circ} \mathbf{C}\right)$ & SUHI $_{\text {MEAN }}(\mathbf{S p})\left({ }^{\circ} \mathbf{C}\right)$ \\
\hline Africa & $1.1 \pm 0.5$ & $2.0 \pm 0.5$ & $2.4 \pm 1.0$ \\
\hline America & $1.9 \pm 0.8$ & $2.8 \pm 1.6$ & $3.3 \pm 2.4$ \\
\hline Asia & $1.4 \pm 1.0$ & $2.3 \pm 1.6$ & $2.7 \pm 1.9$ \\
\hline Europe & $2.4 \pm 0.6$ & $3.1 \pm 0.6$ & $3.6 \pm 0.7$ \\
\hline Oceania & $1.7 \pm 0.6$ & $2.5 \pm 0.3$ & $2.7 \pm 0.7$ \\
\hline${ }^{(1)}$ Population $>20$ millions & $2.4 \pm 0.8$ & $3.3 \pm 1.3$ & $3.5 \pm 1.8$ \\
\hline${ }^{(2)}$ Urban surface $>1000 \mathrm{~km}{ }^{2}$ & $2.1 \pm 0.8$ & $3.0 \pm 1.3$ & $3.3 \pm 2.0$ \\
\hline${ }^{(3)}$ Coast distance $>100 \mathrm{~km}$ & $1.9 \pm 0.9$ & $2.7 \pm 1.3$ & $3.2 \pm 1.5$ \\
\hline${ }^{(4)}$ Elevation $>1 \mathrm{~km}$ & $1.5 \pm 1.1$ & $2.9 \pm 1.7$ & $2.8 \pm 1.5$ \\
\hline$(5)$ Equatorial & $1.4 \pm 0.9$ & $2.4 \pm 1.6$ & $2.8 \pm 1.9$ \\
\hline Arid & $1.2 \pm 0.9$ & $2.1 \pm 1.5$ & $3.1 \pm 1.7$ \\
\hline Warm Temperate & $2.0 \pm 0.7$ & $2.7 \pm 1.1$ & $3.1 \pm \mathbf{1 . 7}$ \\
\hline Snow & $2.1 \pm 1.1$ & & $\mathbf{2 . 6} \pm \mathbf{1 . 3}$ \\
\hline All (71 agglomerations) & $\mathbf{1 . 8} \pm \mathbf{0 . 9}$ & & \\
\hline
\end{tabular}

(1) Tokyo, New Delhi, Shanghai, Sao Paulo, Ciudad de México, El Cairo, Beijing. (2) Los Angeles, New York, Tokyo, Chicago, Jakarta, Buenos Aires, Beijing, Shanghai, Melbourne, San Diego-Tijuana, Sao Paulo, Rio de Janeiro, Paris, Ciudad de Mexico, Toronto, Sydney, London, Bangkok, New Delhi, Moscow, Ruhr región. (3) Milan, Toulouse, Paris, Antananarivo, Beijing, Berlin, Ruhr región, Ciudad de Mexico, Warsaw, Monterrey, Madrid, Hyderabad, Riyad, Las Vegas, Aktobe, Adis Abeba, Wuhan, Mosocw, Oklahoma City, Yakutsk, Lhasa, Niamey, Asunción, New Delhi, Yinchuan, Manaus, Yamena, Taskent, Ürümqi. (4) Lhasa, Adis Abeba, Ciudad de Mexico, Antananarivo, San José, Yinchun, Caracas. (5) Urban agglomerations are classified in Appendix A according to the five vegetation groups of Köppen [45]: equatorial (13 agglomerations), arid (12 agglomerations), warm temperate (37 agglomerations), and snow (6 agglomerations).

Taking these last values as reference, the average heat island effect of $1.8^{\circ} \mathrm{C}$ for the adjacent surrounding area increases by $0.8^{\circ} \mathrm{C}$ for $\mathrm{Sf}$ and $1.3^{\circ} \mathrm{C}$ for Sp, which means that, considering this average as a representative on a global scale and assuming a linear warming trend of $0.18 \mathrm{~K}$ per decade [44], the inhabitants of the urban agglomerations in the world are already suffering the effects of the warming that will be reached by the inhabitants of the adjacent surrounding area in the next century.

It is also noted that Europe is the continent with the highest values of SUHI in the three reference areas, with Africa being the continent with the lowest values. High values are also observed in the seven agglomerations with more than 20 million inhabitants, being $0.3^{\circ} \mathrm{C}$ higher than those obtained for agglomerations with surfaces above $1000 \mathrm{~km}^{2}$. With regard to the agglomerations situated at a distance of more than $1000 \mathrm{~km}$ from the coast, values similar to the world average are obtained, with the elevation producing a slight decrease of $0.3^{\circ} \mathrm{C}$ compared with the average in Su. Finally, in terms of climate, the highest values are found in warm temperate and snow climates, and the lowest in the equatorial and arid climates.

\subsection{UTFVI}

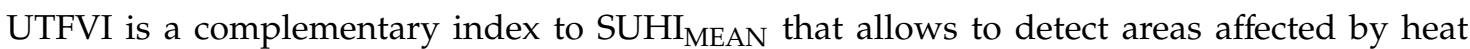
accumulation within the urban agglomeration. In Figure 6, we present the maximum values of the UFTVI index for each urban agglomeration. The highest values are obtained for the urban agglomerations of San José and Ürümqi, followed by Mexico City, New York, Los Angeles, Toronto, Jakarta, Kuala Lumpur, and Buenos Aires. 


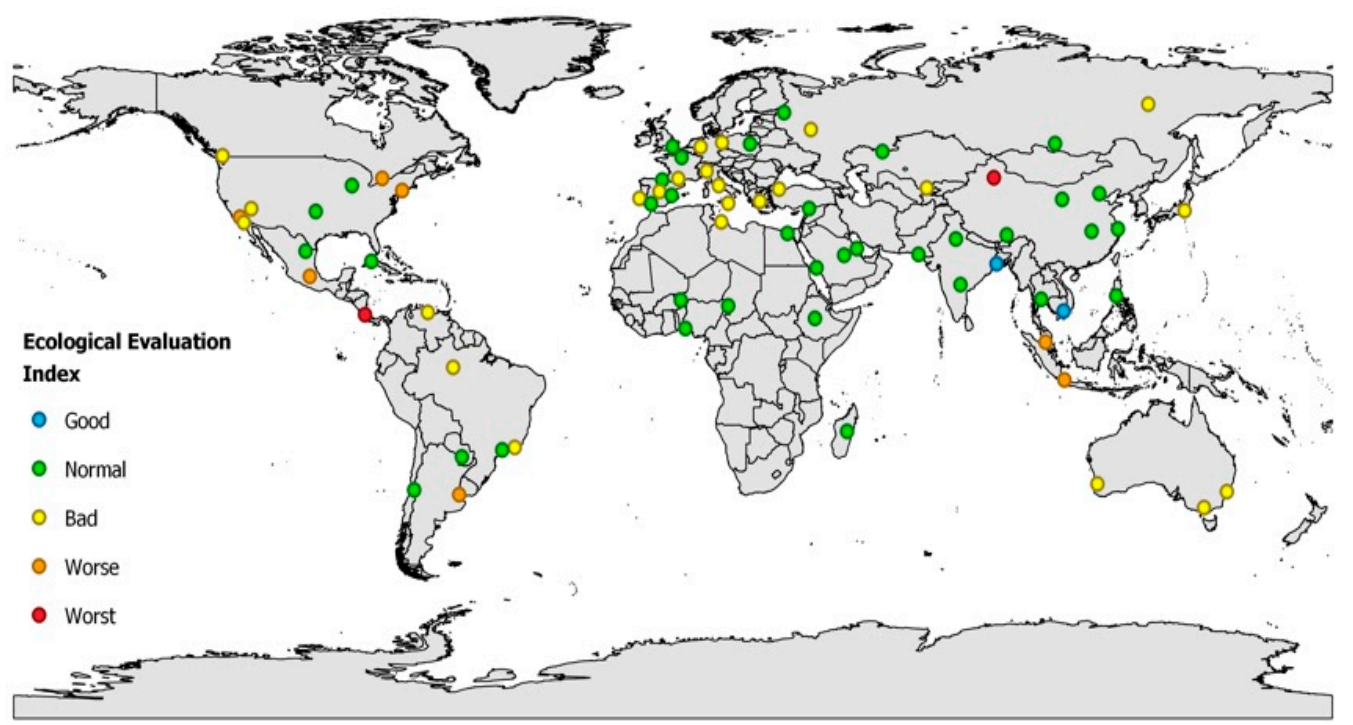

Figure 6. Map of the maximum values (see Appendix A) of the UTFVI for the urban agglomeration areas (A) and the sea and land surface temperature radiometer (SLSTR) Sentinel 3A images selected in this paper. The colors indicate the specific ecological evaluation according to Table 1.

\section{3. $D I$}

With regard to the DI index, the values are correlated to climate, geographical location, and altitude, so that, in some cases, the accumulation of temperature in urban areas allows a transition from cold to comfortable categories (e.g., Vancouver). Figure 7 shows the map of maximum DI values for the 71 urban areas considered. The highest values are obtained for the urban agglomerations of Wuham, Karachi, Shanghai, Manila, Asunción, and Tokyo. Note that, with the exception of Irkutsk, Addis Abeba, and Lhasa, all agglomerations have values above $20^{\circ} \mathrm{C}$.

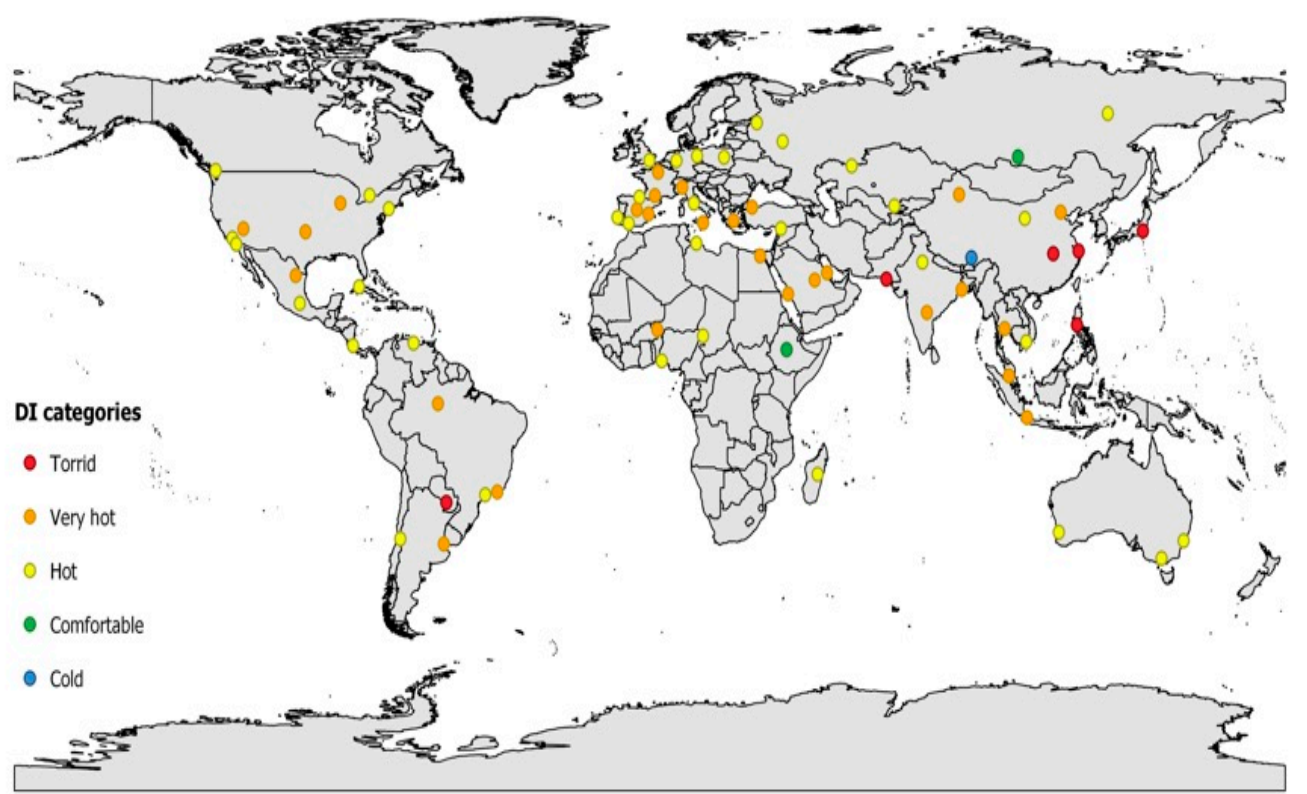

Figure 7. Map of the maximum values (see Table A2 of Appendix A) of the Discomfort Index (DI $\mathrm{MAX}_{\text {) }}$ for the urban agglomeration areas selected in this paper. The colors indicated the DI categories according to Table 2 .

Figure 8 shows the maximum and average values of the DI versus the LST $_{\text {URB-MEAN }}$ for the selected agglomerations. As can be seen, $89 \%$ of the 71 agglomerations have a $\mathrm{DI}_{\text {MEAN }}$ above $20{ }^{\circ} \mathrm{C}$ 
(hot) and $10 \%$ are very hot (see Table 2 ). As for the $\mathrm{DI}_{\mathrm{MAX}}, 37 \%$ of the urban agglomeration are very hot and $9 \%$ are torrid.

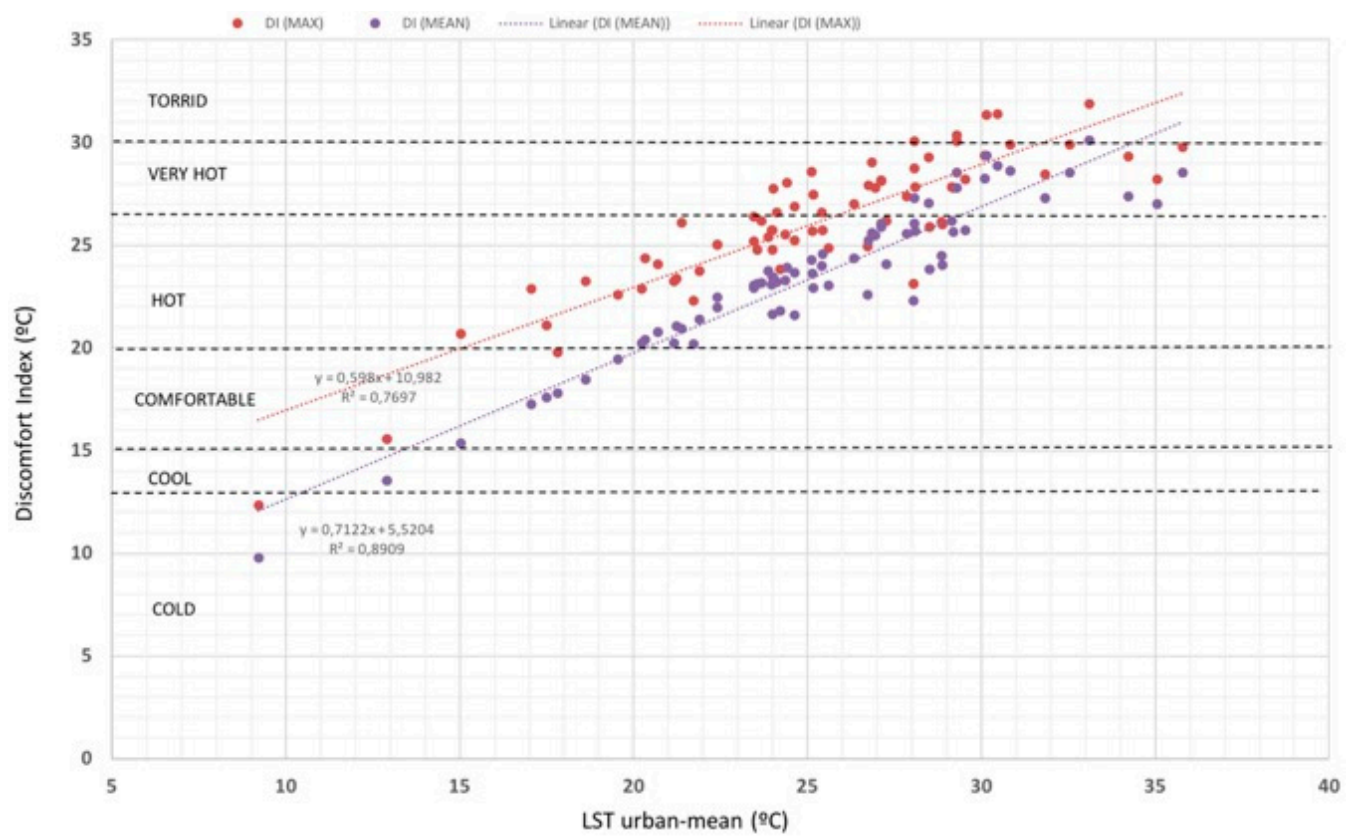

Figure 8. Maximum (red points) and mean (purple points) values of Discomfort Index (DI) versus LST $_{\text {URB-MEAN }}$ obtained from the SLSTR Level-2 land surface temperature (LST) product.

Finally, to facilitate the comparison, a ranking of the 20 urban agglomerations with highest values of $\mathrm{SUHI}_{\text {MEAN }}, \mathrm{DI}_{\text {MEAN }}$, and UTFVI $\mathrm{UAX}_{\text {ix }}$ is presented in Table 4.

Table 4. Urban agglomerations with highest $\mathrm{SUHI}_{\mathrm{MEAN}}$, with respect to the urban adjacent surrounding (Su), $\mathrm{UTFVI}_{\mathrm{MAX}}$, and DI MEAN for the Sentinel 3A images selected.

\begin{tabular}{|c|c|c|c|c|c|c|}
\hline \multirow{2}{*}{$\begin{array}{c}\text { RANKING } \\
1\end{array}$} & \multicolumn{2}{|c|}{ SUHI $_{\text {MEAN }}(\mathrm{Su})\left({ }^{\circ} \mathrm{C}\right)$} & \multicolumn{2}{|c|}{ UTFVI $_{\text {MAX }}$} & \multicolumn{2}{|c|}{ DI MEAN $\left({ }^{\circ} \mathrm{C}\right)$} \\
\hline & Saint Petersburg & 3.9 & San José & 0.020 & Wuhan & 30.1 \\
\hline 2 & Ciudad de México & 3.5 & Ürümqi & 0.020 & Shanghai & 29.3 \\
\hline 3 & Athens & 3.1 & Nueva York & 0.019 & Karachi & 28.9 \\
\hline 4 & Moscow & 3.1 & Ciudad México & 0.019 & Monterrey & 28.6 \\
\hline 5 & Kuala Lumpur & 3.0 & Toronto & 0.018 & Hyderabad & 28.5 \\
\hline 6 & Berlin & 2.9 & Los Ángeles & 0.018 & Manila & 28.5 \\
\hline 7 & Beijing & 2.8 & Kuala Lumpur & 0.016 & Kolkata & 28.3 \\
\hline 8 & Tokyo & 2.8 & Yakarta & 0.016 & Asunción & 27.8 \\
\hline 9 & Sao Paulo & 2.8 & Buenos Aires & 0.015 & Las Vegas & 27.4 \\
\hline 10 & Chicago & 2.8 & San Diego & 0.014 & Jeddah & 27.3 \\
\hline 11 & Madrid & 2.7 & Perth & 0.014 & Tokyo & 27.3 \\
\hline 12 & Sevilla & 2.6 & Manaus & 0.013 & Beijing & 27.1 \\
\hline 13 & Paris & 2.6 & Berlín & 0.013 & Riyad & 27.0 \\
\hline 14 & Taskent & 2.6 & Vancouver & 0.013 & El Cairo & 26.2 \\
\hline 15 & Riyad & 2.6 & Estambul & 0.013 & Rio de Janeiro & 26.1 \\
\hline 16 & Milan & 2.5 & Athens & 0.012 & Bangkok & 26.0 \\
\hline 17 & London & 2.5 & Melbourne & $0-012$ & Paris & 25.9 \\
\hline 18 & Rio de Janeiro & 2.4 & Taskent & 0.012 & Madrid & 25.7 \\
\hline 19 & Vancouver & 2.4 & Yakuts & 0.012 & Valencia & 25.7 \\
\hline 20 & Las Vegas & 2.4 & Moscow & 0.011 & Oklahoma City & 25.7 \\
\hline
\end{tabular}

\section{Conclusions}

Retrieval of land surface temperature (LST) from satellite data allows the estimation of the surface urban heat island (SUHI) as the difference between the LST obtained in the urban area and the LST of its surroundings. However, this definition depends on the selection of the urban and its surrounding. 
So far, there is no clear definition in the literature of how to select these reference areas, and thus this makes it extremely difficult to compare the SUHI between different urban agglomerations.

In this work, a methodology was proposed to estimate the SUHI in a precise and simple way in which the urban reference is obtained from the urban area class of the ESA CCI land cover map and three surroundings references are defined: the urban adjacent $\left(S_{U}\right)$, the future adjacent $\left(S_{F}\right)$, and the peri-urban $\left(S_{P}\right)$, which are obtained from mathematical expressions that depend exclusively on the total urban area (A). In addition, two formulations of SUHI are considered: $\mathrm{SUHI}_{\mathrm{MAX}}$ and SUHI MEAN, which evaluate the maximum and average SUHI of the urban area for each of the three surrounding references.

The proposed methodology was applied to the LST level-2 data product obtained from the SLSTR sensor on board the Sentinel-3A satellite in 71 urban agglomerations worldwide. To complete the study, two additional indices were considered: the Urban Thermal Field Variation Index (UTFVI) and the Discomfort Index (DI), which proved to be complementary to the SUHI phenomenon.

Once the methodology was presented and applied, future work will require a systematic evaluation of $\mathrm{SUHI}_{\mathrm{MAX}}$ and $\mathrm{SUHI}_{\text {MEAN }}$ in urban agglomerations around the world in order to analyse the impact of latitude, longitude, morphology of the urban area, season, distance from ocean, as well as the impact of global warming, which will make necessary to take preventive measures against episodes of heat waves that will be increasingly intense and frequent.

Author Contributions: Conceptualization, J.A.S.; methodology, J.A.S.;; software, J.A.S.; and I.I.; validation, J.A.S.; and I.I.;; formal analysis, J.A.S.; and I.I.; investigation, J.A.S.; and I.I.; resources, José Antonio Sobrino; data curation, J.A.S.; and I.I.; writing-original draft, J.A.S.; and I.I.; writing-review and editing, J.A.S.; visualization, J.A.S.; and I.I.; supervision, J.A.S.; project administration, J.A.S.; funding acquisition, J.A.S. All authors have read and agreed to the published version of the manuscript.

Funding: This research was funded by Ministerio de Ciencia, Innovación y Universidades project ESP2017-85770-R.

Acknowledgments: The authors thank the European Space Agency (ESA) Sentinel 3 SLSTR Level-2 LST product, the ESA Climate Change Initiative Land Cover 2015, the NASA AIRS L3 product, and the UN Department of Economic and Social Affairs, Population Division (2018) for making data freely available and to M.J. Rubio-Lara for the artistic view of Figure 1.

Conflicts of Interest: The authors declare no conflict of interest. The funders had no role in the design of the study; in the collection, analyses, or interpretation of data; in the writing of the manuscript; or in the decision to publish the results.

\section{Appendix A}

Characteristics of the Urban Agglomerations Selected (see Table A1)

Table A1. Urban agglomerations selected in the present paper. CITY is the name of the urban agglomeration. LAT and LON are the latitude and longitude. HEIGHT is the average elevation above sea level in meters. CLIMATE indicates the climatic zone according to Köppen-Geiger classification, see Table 1 of [45]. AREA is the extension in $\mathrm{km}^{2}$ of the urban agglomeration according to [33]. POPULATION is the number of inhabitants in thousands, referring to 2018 [46].

\begin{tabular}{|c|c|c|c|c|c|c|}
\hline CITY. & LAT & LON & $\begin{array}{l}\text { HEIGHT } \\
\text { (m) }\end{array}$ & CLIMATE & $\begin{array}{l}\text { AREA } \\
\left(\mathrm{km}^{2}\right)\end{array}$ & $\begin{array}{c}\text { POPULATION } \\
\text { (Thousands) }\end{array}$ \\
\hline Adís Abeba & 9.03 & 38.74 & 2355.00 & Cwb & 205 & 4400 \\
\hline Antananarivo & -18.94 & 47.52 & 1435.00 & Cwb, Cfb & 143 & 3058 \\
\hline Cairo & 30.06 & 31.24 & 23.00 & BWh & 690 & 20,076 \\
\hline Lagos & 6.52 & 3.38 & 41.00 & Aw & 798 & 13,463 \\
\hline Niamey & 13.51 & 2.11 & 207.00 & BSh & 65 & 1214 \\
\hline Tripoli & 32.89 & 13.19 & 81.00 & BSh & 282 & 1158 \\
\hline Yamena & 12.12 & 15.07 & 298.00 & BSh & 92 & 1323 \\
\hline Chicago & 41.90 & -87.65 & 182.00 & Dfa & 4860 & 8864 \\
\hline Las Vegas & 36.17 & -115.14 & 610.00 & BWk & 703 & 2541 \\
\hline Los Angeles & 34.05 & -118.24 & 71.00 & $\mathrm{Csb}$ & 5791 & 12,458 \\
\hline
\end{tabular}


Table A1. Cont.

\begin{tabular}{|c|c|c|c|c|c|c|}
\hline CITY. & LAT & LON & $\begin{array}{l}\text { HEIGHT } \\
\text { (m) }\end{array}$ & CLIMATE & $\begin{array}{l}\text { AREA } \\
\left(\mathbf{k m}^{2}\right)\end{array}$ & $\begin{array}{l}\text { POPULATION } \\
\text { (Thousands) }\end{array}$ \\
\hline New York & 40.67 & -73.94 & 10.00 & Cfa & 5765 & 18,819 \\
\hline Oklahoma City & 35.48 & -97.54 & 366.00 & Cfa & 613 & 969 \\
\hline San Diego-Tijuana & 32.72 & -117.16 & 22.00 & Csa & 1541 & 5270 \\
\hline Toronto & 43.67 & -79.39 & 76.00 & $\mathrm{Dfb}$ & 1378 & 6082 \\
\hline Vancouver & 49.25 & -122.98 & 3.00 & $\mathrm{Cfb}$ & 600 & 2531 \\
\hline Habanna & 23.14 & -82.36 & 59.00 & Aw & 192 & 2136 \\
\hline México City & 19.42 & -99.15 & 2250.00 & Cwb & 1382 & 21,581 \\
\hline Monterrey & 25.67 & -100.31 & 530.00 & BSh & 468 & 4712 \\
\hline San José & 9.93 & -84.08 & 1300.00 & $\mathrm{Am}, \mathrm{Cfb}$ & 310 & 1358 \\
\hline Asunción & -25.28 & -57.64 & 89.00 & $\mathrm{Cfa}$ & 408 & 3222 \\
\hline Buenos Aires & -34.60 & -58.38 & 25.00 & Cfa & 2032 & 14,967 \\
\hline Caracas & 10.50 & -66.93 & 1000.00 & Aw & 176 & 2935 \\
\hline Manaus & -3.10 & -60.02 & 92.00 & $\mathrm{Am}$ & 225 & 2171 \\
\hline Río de Janeiro & -22.91 & -43.20 & 11.00 & Aw & 1513 & 13,293 \\
\hline Santiago de Chile & -33.45 & -70.67 & 520.00 & $\mathrm{Csb}$ & 552 & 6680 \\
\hline São Paulo & -23.55 & -46.63 & 760.00 & Cfa & 1526 & 21,650 \\
\hline Aktobe & 50.30 & 57.17 & 225.00 & Dfa & 69 & 420 \\
\hline Alepo & 36.20 & 37.15 & 379.00 & Csa & 133 & 1754 \\
\hline Bangkok & 13.75 & 100.52 & 1.50 & Aw & 1231 & 10,156 \\
\hline Beijing & 39.91 & 116.39 & 43.00 & Dwa & 1951 & 19,618 \\
\hline Dammam & 26.28 & 50.20 & 10.00 & BWh & 391 & 1197 \\
\hline Ho Chi Minh & 10.82 & 106.63 & 19.00 & Aw & 632 & 8145 \\
\hline Hyderabad & 17.37 & 78.48 & 505.00 & Aw & 498 & 9482 \\
\hline Irkutsk & 52.28 & 104.30 & 440.00 & Dwc & 109 & 633 \\
\hline Jakarta & -6.21 & 106.85 & 4.00 & Af & 4481 & 10,517 \\
\hline Jeddah & 21.54 & 39.17 & 12.00 & BWh & 360 & 4433 \\
\hline Karachi & 24.86 & 67.01 & 8.00 & BWh & 415 & 15,400 \\
\hline Kolkata & 22.54 & 88.34 & 9.00 & Aw & 795 & 14,681 \\
\hline Kuala Lumpur & 3.15 & 101.70 & 66.00 & Af & 963 & 7564 \\
\hline Lhasa & 29.65 & 91.10 & 3650.00 & ET & 58 & 330 \\
\hline Manila & 14.58 & 121.00 & 5.00 & Am & 794 & 13,482 \\
\hline New Delhi & 28.67 & 77.22 & 239.00 & Cwa, BSh & 1181 & 28,514 \\
\hline Riyad & 24.65 & 46.71 & 612.00 & BWh & 879 & 6907 \\
\hline Shanghai & 31.17 & 121.47 & 4.00 & Cfa & 1739 & 25,582 \\
\hline Taskent & 41.30 & 69.27 & 455.00 & Csa & 390 & 2464 \\
\hline Tokyo & 35.68 & 139.68 & 6.00 & $\mathrm{Cfa}$ & 5028 & 37,468 \\
\hline Ürümqi & 43.83 & 87.60 & 830.00 & Bsk & 241 & 4011 \\
\hline Wuhan & 30.57 & 114.28 & 37.00 & Cfa & 546 & 8176 \\
\hline Yakutsk & 62.03 & 129.73 & 95.00 & Dfd & 80 & 318 \\
\hline Yinchuan & 38.48 & 106.23 & 1100.00 & BWk & 139 & 1483 \\
\hline Atenas & 37.98 & 23.72 & 170.00 & Csa & 424 & 3156 \\
\hline Berlin & 52.52 & 13.38 & 34.00 & $\mathrm{Cfb}$ & 604 & 3552 \\
\hline Bilbao & 43.26 & -2.95 & 6.00 & $\mathrm{Cfb}$ & 70 & 352 \\
\hline Catania & 37.50 & 15.09 & 7.00 & Csa & 143 & 586 \\
\hline Istambul & 41.01 & 28.96 & 40.00 & Csa & 881 & 14,751 \\
\hline Lisbon & 38.72 & -9.17 & 2.00 & Csa & 426 & 2927 \\
\hline London & 51.51 & -0.13 & 35.00 & $\mathrm{Cfb}$ & 1233 & 9046 \\
\hline Madrid & 40.42 & -3.69 & 657.00 & Csa & 318 & 6497 \\
\hline Milán & 45.46 & 9.19 & 120.00 & Cfa & 688 & 3132 \\
\hline Moscow & 55.76 & 37.62 & 156.00 & $\mathrm{Dfb}$ & 1111 & 12,410 \\
\hline Paris & 48.86 & 2.35 & 33.00 & $\mathrm{Cfb}$ & 1457 & 10,901 \\
\hline Roma & 41.89 & 12.48 & 21.00 & Csa & 293 & 4210 \\
\hline Ruhr region & 51.47 & 7.55 & 45.00 & $\mathrm{Cfb}$ & 1006 & 5119 \\
\hline Saint Petersburg & 59.95 & 30.32 & 3.00 & $\mathrm{Dfb}$ & 425 & 5383 \\
\hline Sevilla & 37.39 & -5.98 & 200.00 & Csa & 113 & 707 \\
\hline Toulouse & 43.60 & 1.44 & 141.00 & $\mathrm{Cfb}$ & 252 & 997 \\
\hline Valencia & 39.47 & -0.38 & 16.00 & Csa & 197 & 830 \\
\hline Warsaw & 52.22 & 21.03 & 100.00 & $\mathrm{Cfb}$ & 360 & 1768 \\
\hline Melbourne & -37.82 & 144.96 & 31.00 & $\mathrm{Cfb}$ & 1656 & 4771 \\
\hline Perth & -31.95 & 115.86 & 0.00 & Csa & 951 & 1991 \\
\hline Sydney & -33.87 & 151.20 & 3.00 & Cfa & 1325 & 4792 \\
\hline
\end{tabular}


Table A2. The results for the urban agglomerations. LST is the average temperature of the urban area in $\mathrm{K}_{\text {(LST }} \mathrm{LRBAN}_{\text {MEAN }}$ ). Columns 3 to 8 give the values for the surroundings $\mathrm{Su}$, Sf, and Sp of SUHI $\mathrm{MAX}$ and $\mathrm{SUHI}_{\text {MEAN }}$, respectively. UTFVI MAX and $\mathrm{DI}_{\mathrm{MAX}}$ are the maximum values of the indices and DATE is the day of the Sentinel $3 \mathrm{~A}$ image.

\begin{tabular}{|c|c|c|c|c|c|c|c|c|c|c|}
\hline CITY & LST (K) & $\begin{array}{c}\text { SUHI } \\
\text { MAX Su }\end{array}$ & Sf & $\mathrm{Sp}$ & $\begin{array}{c}\text { SUHI } \\
\text { MEAN Su }\end{array}$ & Sf & $S p$ & $\begin{array}{l}\text { UTFVI } \\
\text { (MAX) }\end{array}$ & $\begin{array}{c}\text { DI } \\
\text { (MAX) }\end{array}$ & DATE \\
\hline Adís Abeba & 286.40 & 3.46 & 4.48 & 3.79 & 0.85 & 1.87 & 1.18 & 0.009 & 15.57 & $2019 / 01 / 16$ \\
\hline Antananarivo & 294.73 & 2.51 & 4.13 & 4.96 & 0.02 & 1.65 & 2.48 & 0.008 & 23.38 & $2019 / 01 / 16$ \\
\hline Cairo & 302.64 & 3.54 & 4.39 & 4.92 & 1.44 & 2.28 & 2.81 & 0.007 & 27.84 & $2018 / 08 / 13$ \\
\hline Lagos & 297.05 & 3.12 & 4.71 & 6.17 & 1.34 & 2.93 & 4.38 & 0.006 & 24.76 & 2019/04/03 \\
\hline Niamey & 300.46 & 4.23 & 4.98 & 5.27 & 1.53 & 2.27 & 2.57 & 0.009 & 27.79 & 2018/08/04 \\
\hline Tripoli & 302.39 & 4.36 & 4.88 & 5.03 & 1.29 & 1.81 & 1.97 & 0.010 & 26.03 & 2018/07/19 \\
\hline Yamena & 301.56 & 2.40 & 2.81 & 3.17 & 0.91 & 1.31 & 1.67 & 0.005 & 23.13 & 2019/04/03 \\
\hline Chicago & 301.36 & 3.94 & 6.26 & 6.19 & 1.71 & 4.02 & 3.95 & 0.007 & 27.38 & $2018 / 06 / 30$ \\
\hline Las Vegas & 307.72 & 5.38 & 7.74 & 9.18 & 2.38 & 4.74 & 6.17 & 0.010 & 29.32 & 2018/08/04 \\
\hline Los Angeles & 298.13 & 6.78 & 6.75 & 3.48 & 1.35 & 1.32 & -1.95 & 0.018 & 25.25 & $2018 / 08 / 04$ \\
\hline New York & 294.88 & 7.83 & 8.90 & 10.46 & 2.03 & 3.10 & 4.66 & 0.019 & 26.09 & 2018/07/19 \\
\hline Oklahoma City & 302.70 & 4.75 & 5.62 & 5.64 & 1.87 & 2.74 & 2.76 & 0.009 & 27.80 & $2018 / 07 / 22$ \\
\hline San Diego-Tijuana & 297.49 & 5.54 & 4.91 & 4.23 & 1.18 & 0.56 & -0.13 & 0.014 & 24.79 & $2018 / 08 / 04$ \\
\hline Toronto & 292.13 & 6.81 & 7.08 & 7.48 & 1.33 & 1.60 & 1.99 & 0.018 & 23.26 & $2018 / 07 / 22$ \\
\hline Vancouver & 291.00 & 6.23 & 9.86 & 12.18 & 2.43 & 6.07 & 8.38 & 0.013 & 21.09 & $2018 / 08 / 04$ \\
\hline Habanna & 297.85 & 4.40 & 5.40 & 5.39 & 1.83 & 2.83 & 2.82 & 0.009 & 25.52 & $2019 / 04 / 26$ \\
\hline México City & 288.54 & 9.11 & 10.28 & 9.15 & 3.50 & 4.67 & 3.54 & 0.019 & 20.68 & $2018 / 07 / 22$ \\
\hline Monterrey & 304.33 & 3.85 & 5.42 & 6.87 & 2.31 & 3.88 & 5.33 & 0.005 & 29.92 & $2018 / 07 / 22$ \\
\hline San José & 290.56 & 6.64 & 7.64 & 8.46 & 0.76 & 1.76 & 2.58 & 0.020 & 22.86 & $2019 / 04 / 26$ \\
\hline Asunción & 302.79 & 3.96 & 4.43 & 4.88 & 1.38 & 1.85 & 2.31 & 0.008 & 30.07 & $2019 / 01 / 23$ \\
\hline Buenos Aires & 297.92 & 6.36 & 6.73 & 8.93 & 1.87 & 2.23 & 4.44 & 0.015 & 28.04 & $2019 / 01 / 23$ \\
\hline Caracas & 293.74 & 5.06 & 5.02 & 6.26 & 2.23 & 2.19 & 3.42 & 0.010 & 22.89 & 2018/07/19 \\
\hline Manaus & 300.36 & 4.16 & 3.54 & 4.40 & 0.23 & -0.39 & 0.47 & 0.013 & 29.03 & 2018/07/19 \\
\hline Río de Janeiro & 301.57 & 5.69 & 8.33 & 9.03 & 2.44 & 5.08 & 5.77 & 0.011 & 28.75 & 2019/01/29 \\
\hline Santiago de Chile & 295.23 & 3.73 & 4.54 & 6.92 & 0.93 & 1.74 & 4.12 & 0.009 & 22.31 & $2019 / 01 / 26$ \\
\hline São Paulo & 298.65 & 5.23 & 5.51 & 4.72 & 2.75 & 3.02 & 2.24 & 0.008 & 25.69 & $2019 / 01 / 29$ \\
\hline Aktobe & 297.51 & 3.27 & 3.70 & 3.91 & 0.76 & 1.19 & 1.40 & 0.008 & 25.71 & $2019 / 07 / 19$ \\
\hline Alepo & 299.10 & 3.62 & 4.07 & 4.26 & 1.21 & 1.66 & 1.85 & 0.008 & 24.85 & $2018 / 08 / 14$ \\
\hline Bangkok & 300.61 & 2.62 & 3.37 & 3.77 & 0.25 & 1.00 & 1.40 & 0.008 & 28.15 & $2019 / 03 / 11$ \\
\hline Beijing & 301.99 & 5.31 & 3.64 & 3.41 & 2.80 & 1.48 & 1.25 & 0.008 & 29.26 & $2018 / 07 / 28$ \\
\hline Dammam & 309.29 & 1.91 & 2.11 & 2.10 & -0.04 & 0.16 & 0.15 & 0.006 & 29.79 & $2018 / 08 / 13$ \\
\hline Ho Chi Minh & 298.95 & 1.70 & 2.16 & 2.69 & 0.38 & 0.83 & 1.37 & 0.004 & 25.74 & $2019 / 03 / 11$ \\
\hline Hyderabad & 306.04 & 3.49 & 4.39 & 5.07 & 1.69 & 2.58 & 3.27 & 0.006 & 29.91 & $2019 / 05 / 16$ \\
\hline Irkutsk & 291.32 & 3.38 & 3.60 & 4.08 & 1.15 & 1.37 & 1.84 & 0.008 & 19.77 & $2018 / 07 / 14$ \\
\hline Jakarta & 297.52 & 6.93 & 9.13 & 8.98 & 2.14 & 4.34 & 4.19 & 0.016 & 27.75 & $2018 / 07 / 16$ \\
\hline Jeddah & 305.33 & 1.98 & 2.46 & 2.84 & 0.43 & 0.91 & 1.29 & 0.005 & 28.44 & $2018 / 08 / 14$ \\
\hline Karachi & 303.97 & 2.66 & 3.17 & 3.12 & -0.22 & 0.29 & 0.24 & 0.009 & 31.38 & $2019 / 05 / 23$ \\
\hline Kolkata & 303.59 & 2.22 & 2.34 & 2.23 & 0.93 & 1.05 & 0.93 & 0.004 & 29.37 & $2019 / 05 / 16$ \\
\hline Kuala Lumpur & 298.62 & 7.90 & 9.05 & 7.57 & 3.04 & 4.18 & 2.70 & 0.016 & 28.59 & $2018 / 07 / 16$ \\
\hline Lhasa & 282.71 & 4.47 & 8.70 & 9.91 & 1.82 & 6.05 & 7.26 & 0.009 & 12.32 & 2019/05/16 \\
\hline Manila & 302.80 & 3.10 & 4.24 & 5.66 & 1.15 & 2.29 & 3.71 & 0.006 & 30.33 & $2019 / 04 / 30$ \\
\hline New Delhi & 300.76 & 5.03 & 5.81 & 5.94 & 2.15 & 2.93 & 3.06 & 0.009 & 26.18 & 2019/05/16 \\
\hline Riyad & 308.55 & 4.56 & 5.75 & 6.57 & 2.56 & 3.75 & 4.57 & 0.006 & 28.21 & $2018 / 07 / 31$ \\
\hline Shanghai & 303.64 & 3.43 & 3.64 & 3.41 & 1.27 & 1.48 & 1.25 & 0.007 & 31.35 & $2018 / 07 / 19$ \\
\hline Taskent & 300.23 & 6.25 & 5.91 & 4.79 & 2.56 & 2.22 & 1.10 & 0.012 & 24.95 & 2018/07/09 \\
\hline Tokyo & 301.59 & 5.82 & 8.26 & 10.02 & 2.80 & 5.24 & 6.99 & 0.010 & 30.06 & $2018 / 07 / 31$ \\
\hline Ürümqi & 298.67 & 6.39 & 6.98 & 9.37 & 0.41 & 1.00 & 3.40 & 0.020 & 27.47 & $2018 / 08 / 11$ \\
\hline Wuhan & 306.60 & 4.06 & 4.37 & 4.71 & 1.93 & 2.24 & 2.57 & 0.007 & 31.87 & $2018 / 07 / 19$ \\
\hline Yakutsk & 294.19 & 4.75 & 5.35 & 6.12 & 1.27 & 1.87 & 2.64 & 0.012 & 24.08 & $2018 / 07 / 07$ \\
\hline Yinchuan & 297.73 & 4.32 & 5.18 & 5.63 & 1.54 & 2.40 & 2.84 & 0.009 & 23.82 & $2018 / 07 / 25$ \\
\hline Atenas & 298.13 & 6.85 & 7.22 & 6.82 & 3.14 & 3.51 & 3.12 & 0.012 & 26.89 & $2018 / 08 / 13$ \\
\hline Berlin & 296.97 & 6.78 & 7.34 & 7.49 & 2.90 & 3.47 & 3.62 & 0.013 & 26.39 & $2018 / 08 / 03$ \\
\hline Bilbao & 297.37 & 3.66 & 4.06 & 4.21 & 1.93 & 2.33 & 2.47 & 0.006 & 25.39 & $2018 / 08 / 02$ \\
\hline Catania & 298.92 & 4.41 & 5.52 & 6.67 & 1.27 & 2.38 & 3.54 & 0.010 & 26.60 & $2018 / 08 / 03$ \\
\hline Istambul & 297.62 & 5.50 & 6.14 & 6.93 & 1.63 & 2.27 & 3.06 & 0.013 & 26.59 & $2018 / 08 / 14$ \\
\hline Lisbon & 302.01 & 5.01 & 5.83 & 6.66 & 1.80 & 2.62 & 3.45 & 0.011 & 25.89 & 2018/08/04 \\
\hline London & 296.97 & 4.84 & 5.92 & 7.06 & 2.49 & 3.56 & 4.71 & 0.008 & 25.21 & $2018 / 08 / 02$ \\
\hline Madrid & 303.03 & 6.09 & 6.52 & 6.98 & 2.70 & 3.13 & 3.58 & 0.011 & 28.21 & $2018 / 08 / 02$ \\
\hline Milán & 299.85 & 5.78 & 6.61 & 7.22 & 2.50 & 3.33 & 3.94 & 0.011 & 27.00 & 2018/07/19 \\
\hline Moscow & 293.05 & 6.47 & 7.37 & 8.03 & 3.06 & 3.96 & 4.62 & 0.012 & 22.59 & $2018 / 07 / 31$ \\
\hline Paris & 300.63 & 5.07 & 6.04 & 6.76 & 2.57 & 3.54 & 4.26 & 0.008 & 28.11 & $2018 / 08 / 03$ \\
\hline Roma & 297.47 & 5.33 & 6.28 & 7.08 & 2.30 & 3.26 & 4.05 & 0.010 & 25.72 & $2018 / 07 / 19$ \\
\hline Ruhr region & 297.17 & 4.56 & 5.64 & 6.14 & 1.29 & 2.37 & 2.88 & 0.011 & 26.16 & $2018 / 08 / 02$ \\
\hline Saint Petersburg & 295.90 & 6.53 & 6.98 & 7.37 & 3.89 & 4.34 & 4.73 & 0.009 & 25.02 & $2018 / 07 / 31$ \\
\hline Sevilla & 302.35 & 5.08 & 5.64 & 6.10 & 2.60 & 3.17 & 3.63 & 0.008 & 26.15 & $2018 / 08 / 01$ \\
\hline Toulouse & 300.27 & 5.33 & 5.94 & 6.19 & 2.21 & 2.82 & 3.07 & 0.010 & 27.90 & $2018 / 08 / 02$ \\
\hline Valencia & 301.59 & 4.44 & 4.76 & 5.22 & 1.75 & 2.07 & 2.53 & 0.009 & 27.83 & $2018 / 08 / 02$ \\
\hline Warsaw & 295.39 & 4.69 & 5.40 & 5.83 & 2.06 & 2.77 & 3.20 & 0.009 & 23.73 & $2018 / 08 / 13$ \\
\hline Melbourne & 294.67 & 5.94 & 6.53 & 6.86 & 2.29 & 2.87 & 3.20 & 0.012 & 23.24 & 2019/01/03 \\
\hline Perth & 293.83 & 5.26 & 6.32 & 5.96 & 1.11 & 2.17 & 1.81 & 0.014 & 24.38 & $2019 / 01 / 15$ \\
\hline Sydney & 295.90 & 5.09 & 5.88 & 6.34 & 1.71 & 2.50 & 2.96 & 0.011 & 25.04 & 2019/01/03 \\
\hline
\end{tabular}


Land surface temperature images (Sentinel-3A SLSTR Level-2 LST product) of the urban agglomerations selected. The images cover the peri-urban area. The polygon is the urban area obtained from ESA CCI [33].

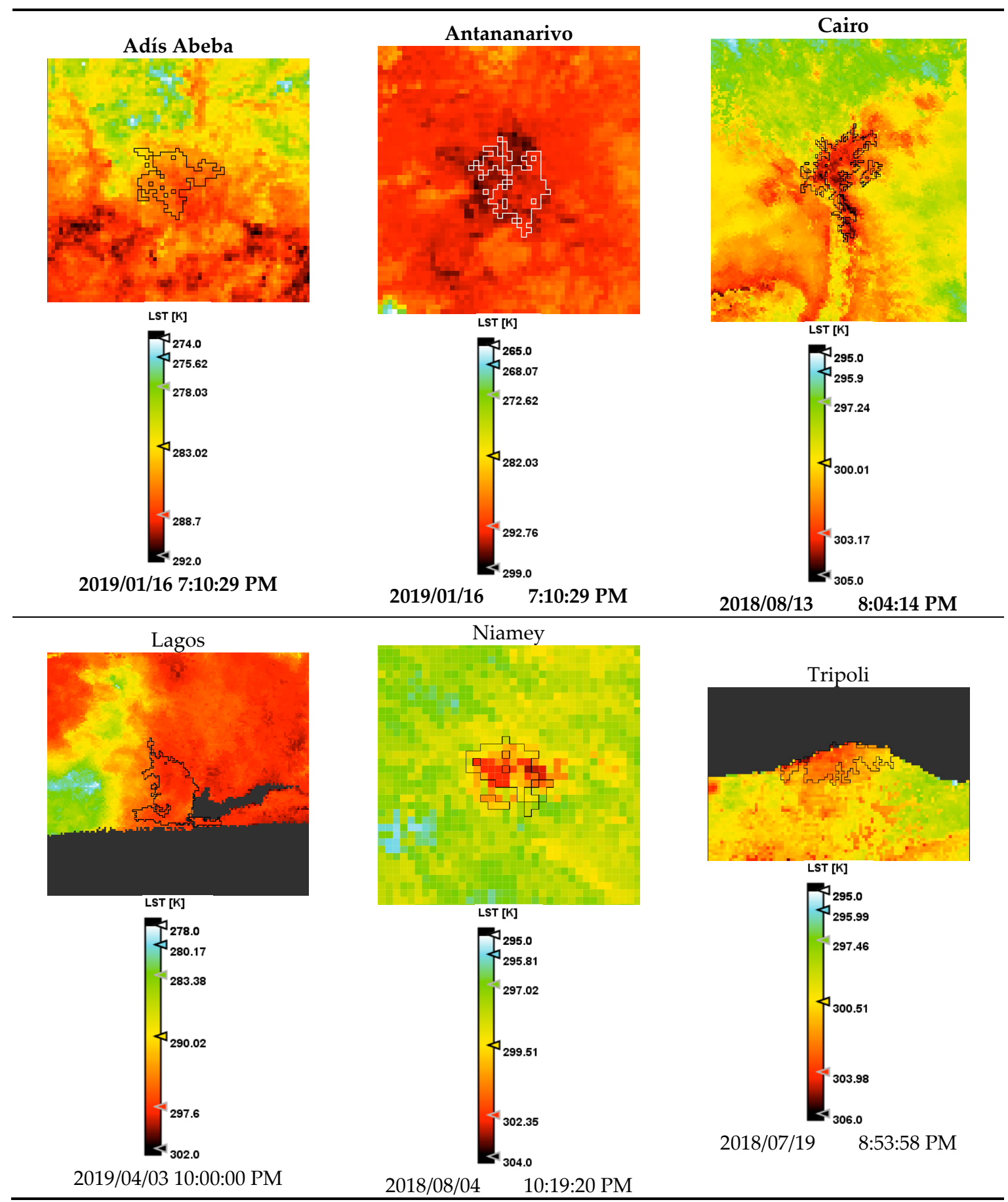

Figure A1. Cont. 


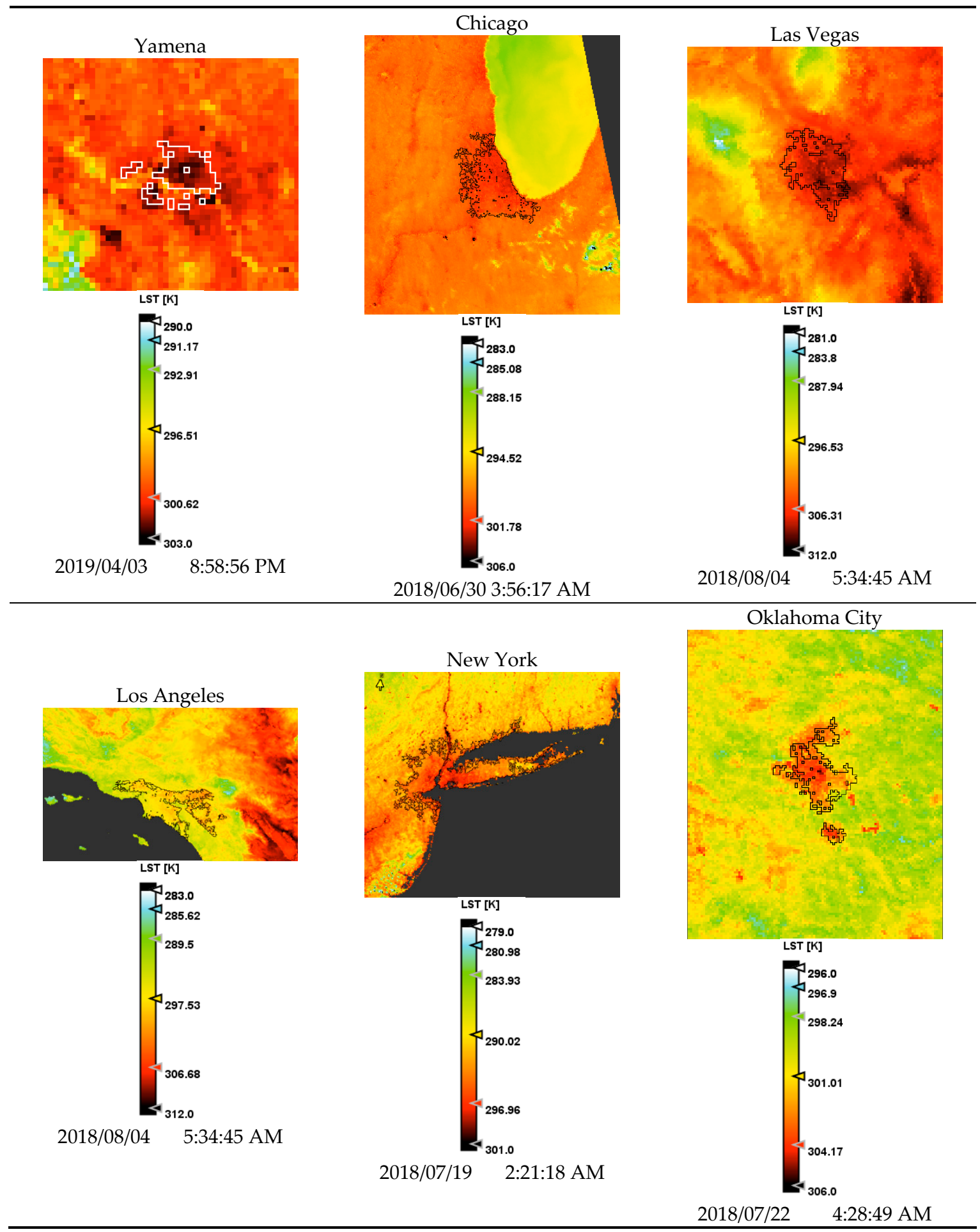

Figure A1. Cont. 


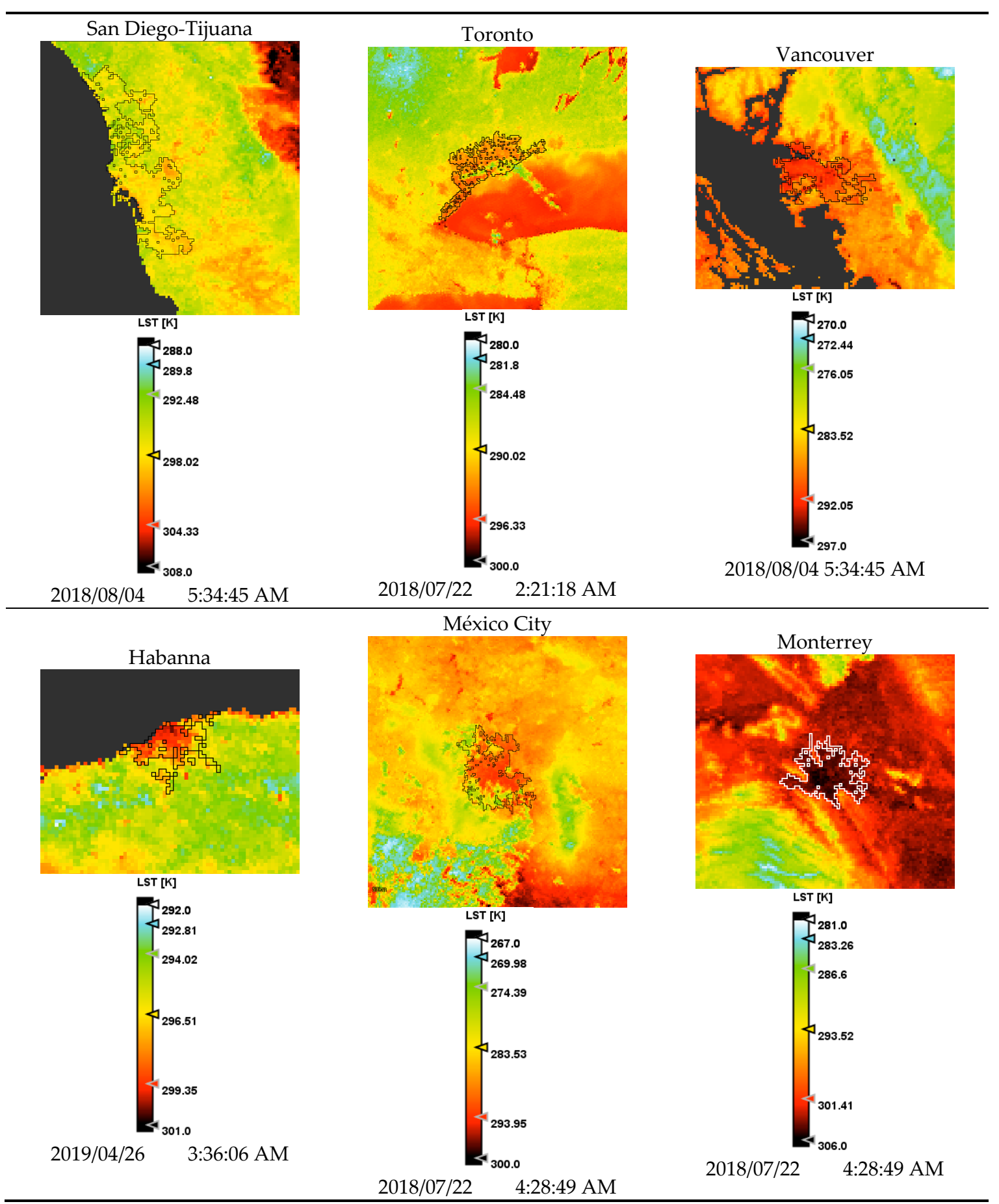

Figure A1. Cont. 


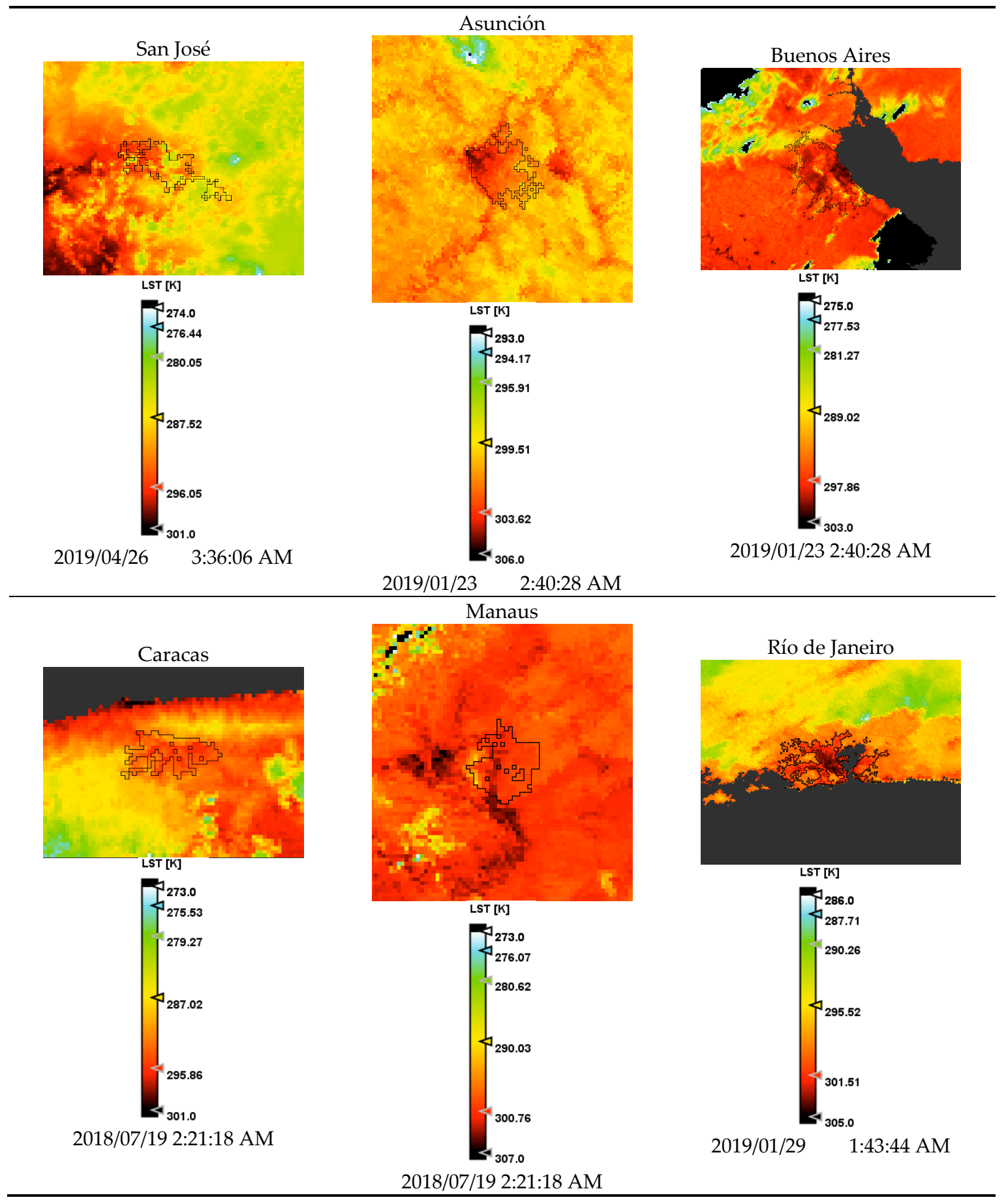

Figure A1. Cont. 


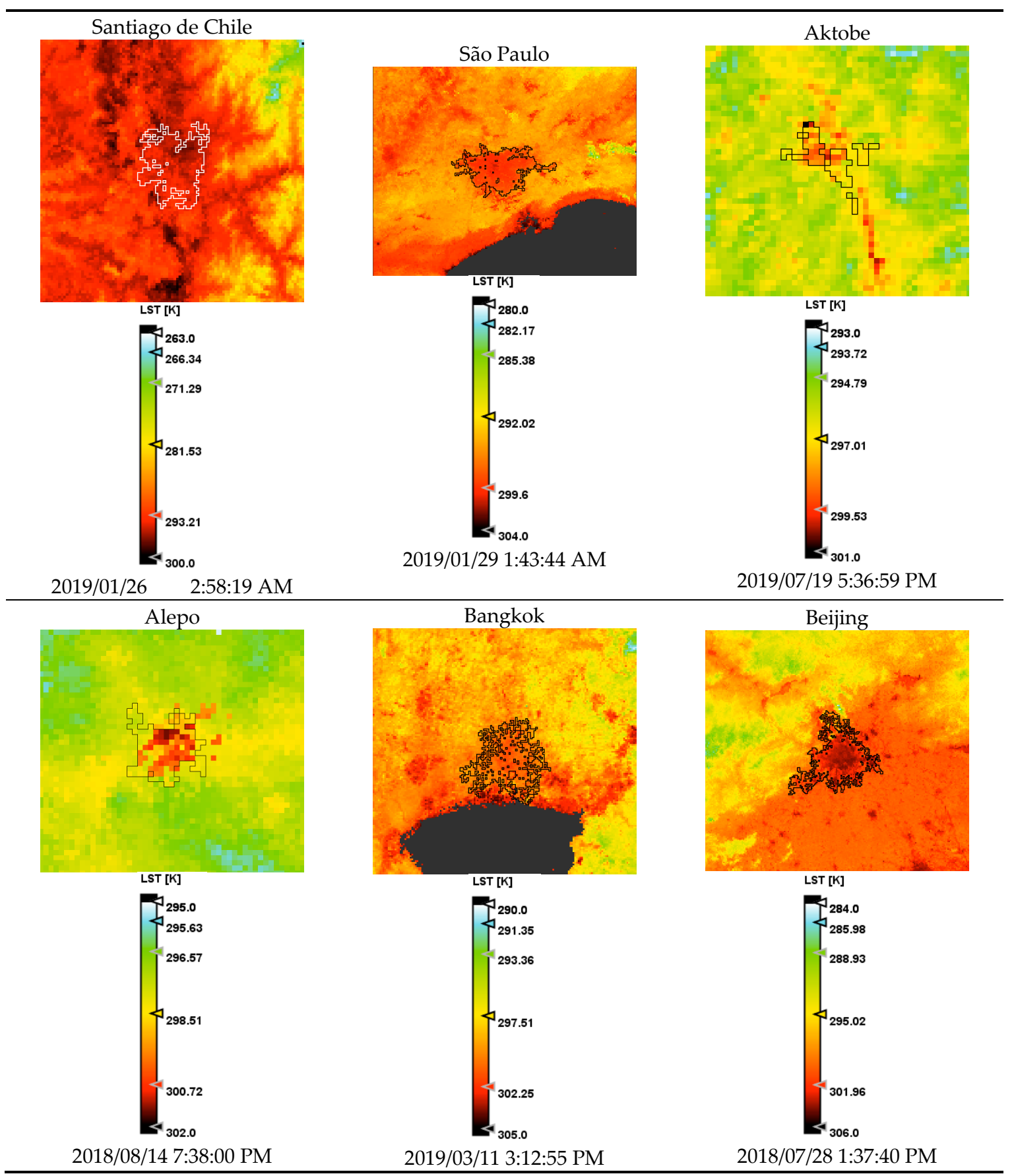

Figure A1. Cont. 


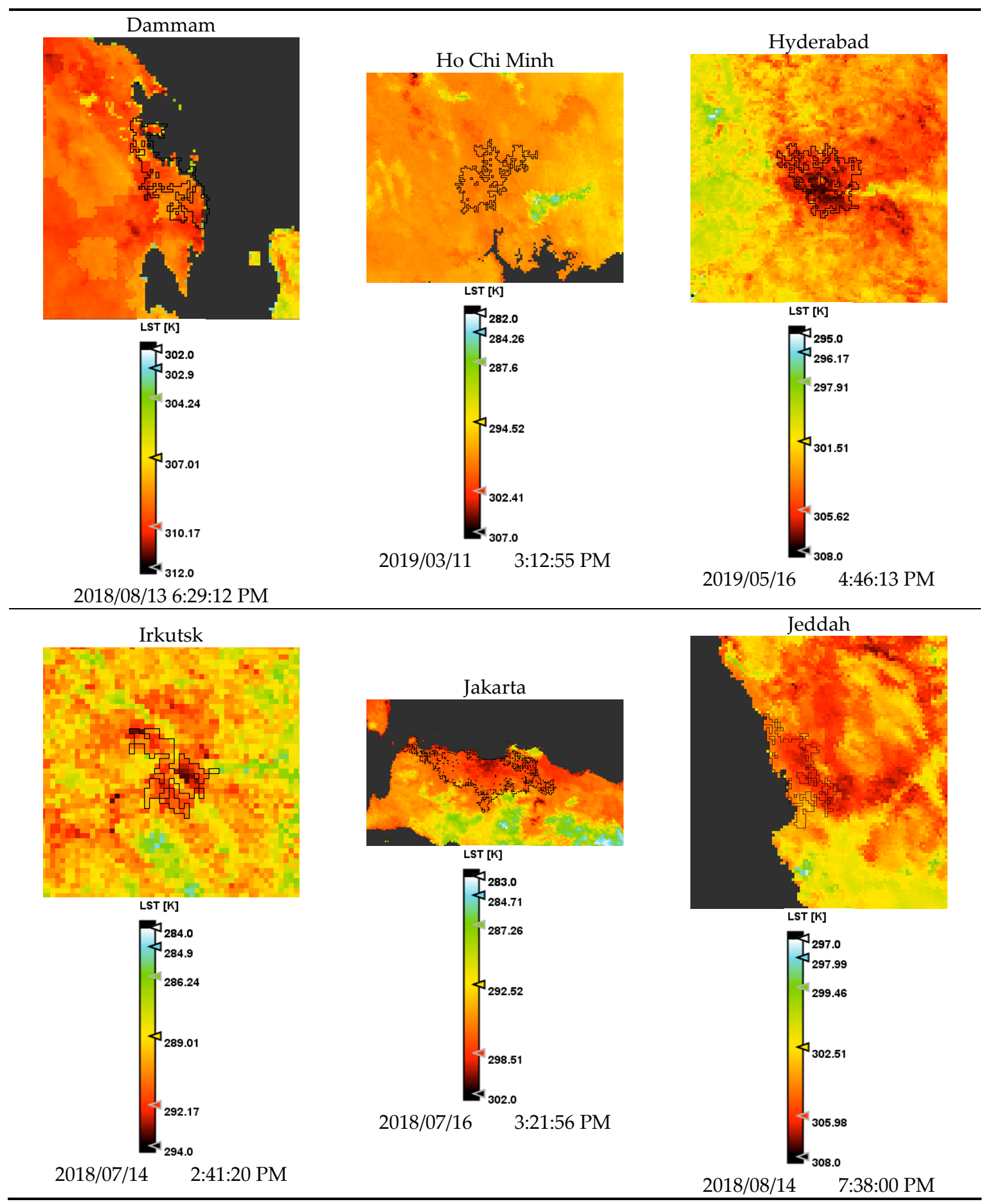

Figure A1. Cont. 


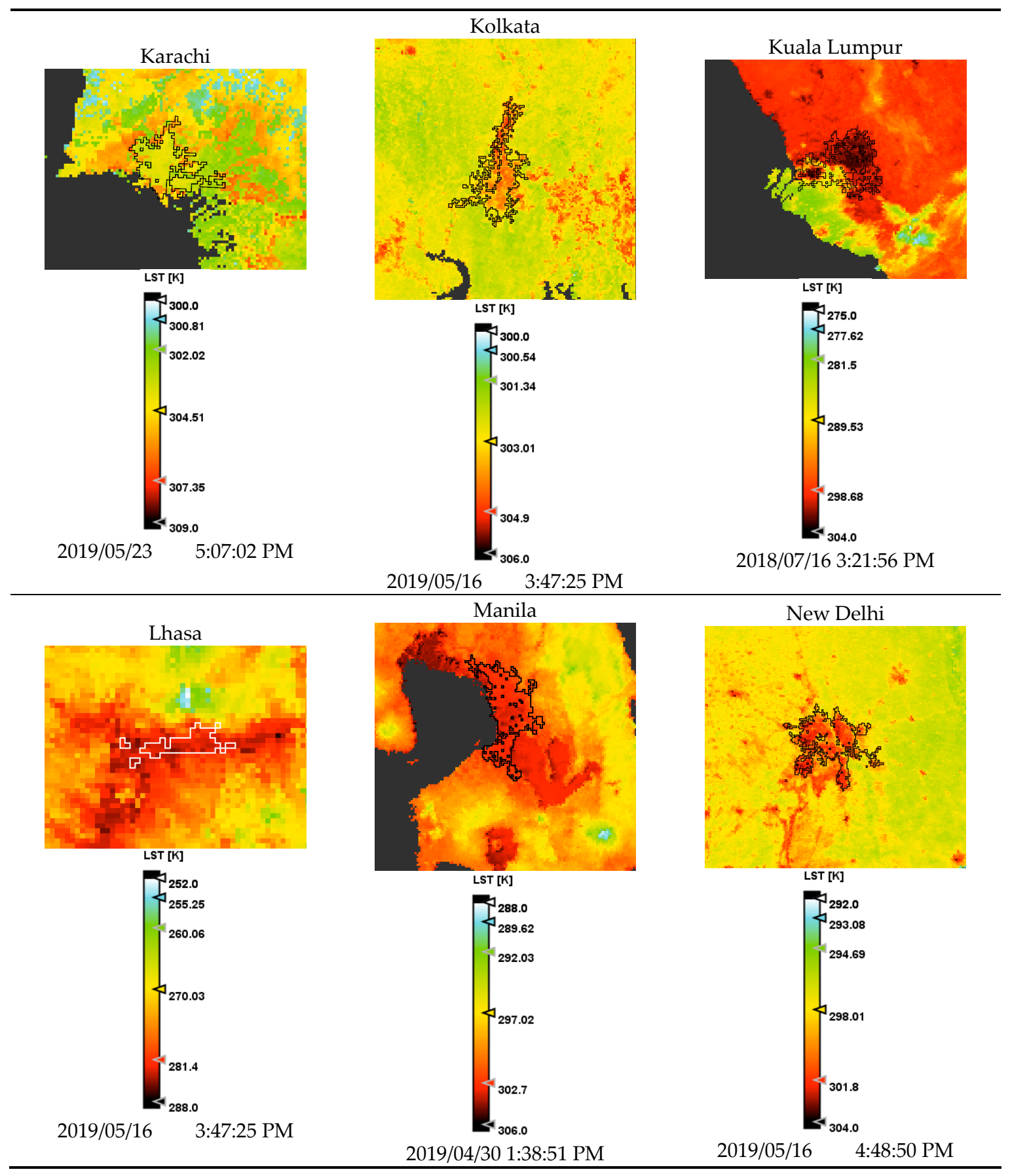

Figure A1. Cont. 


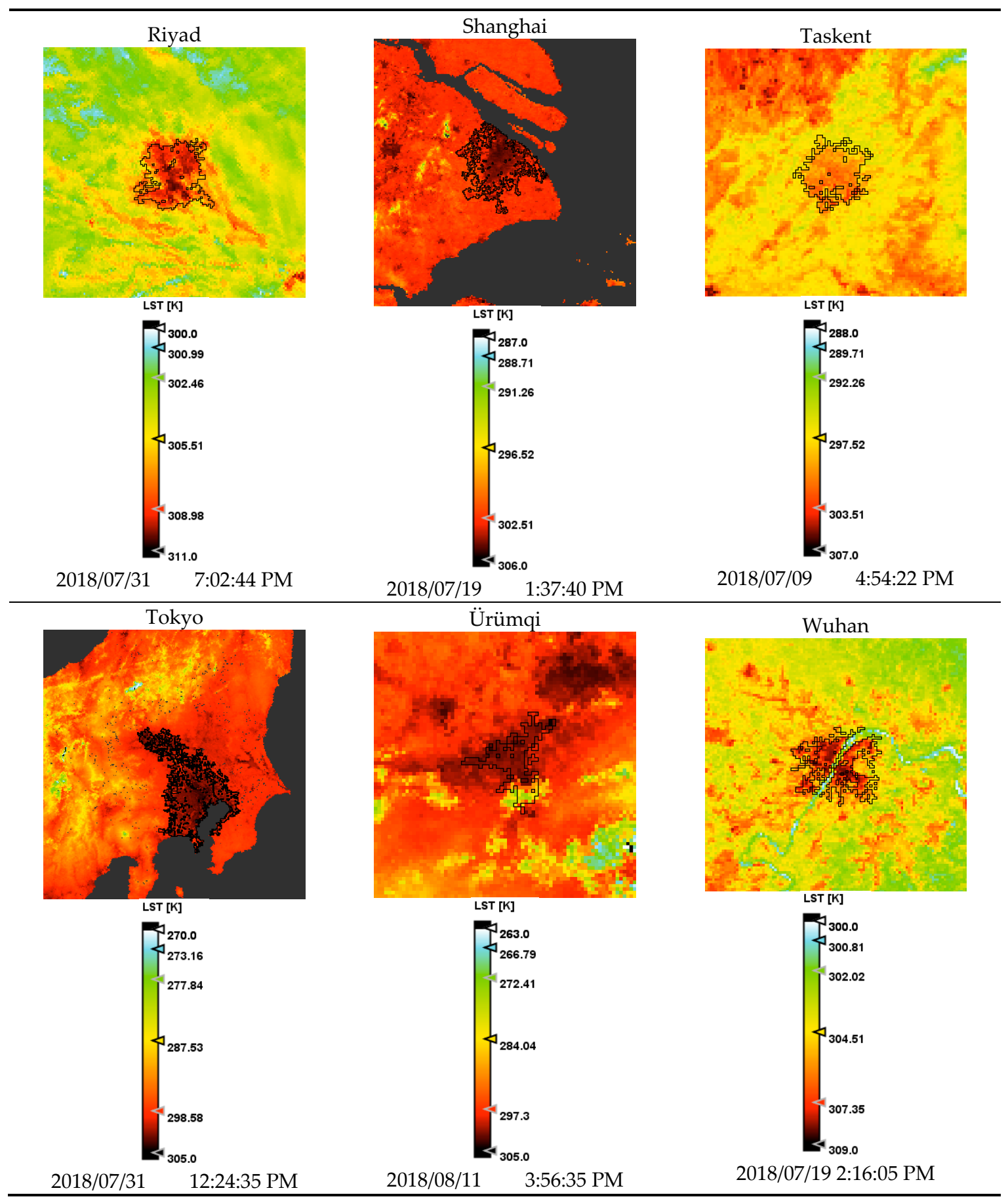

Figure A1. Cont. 


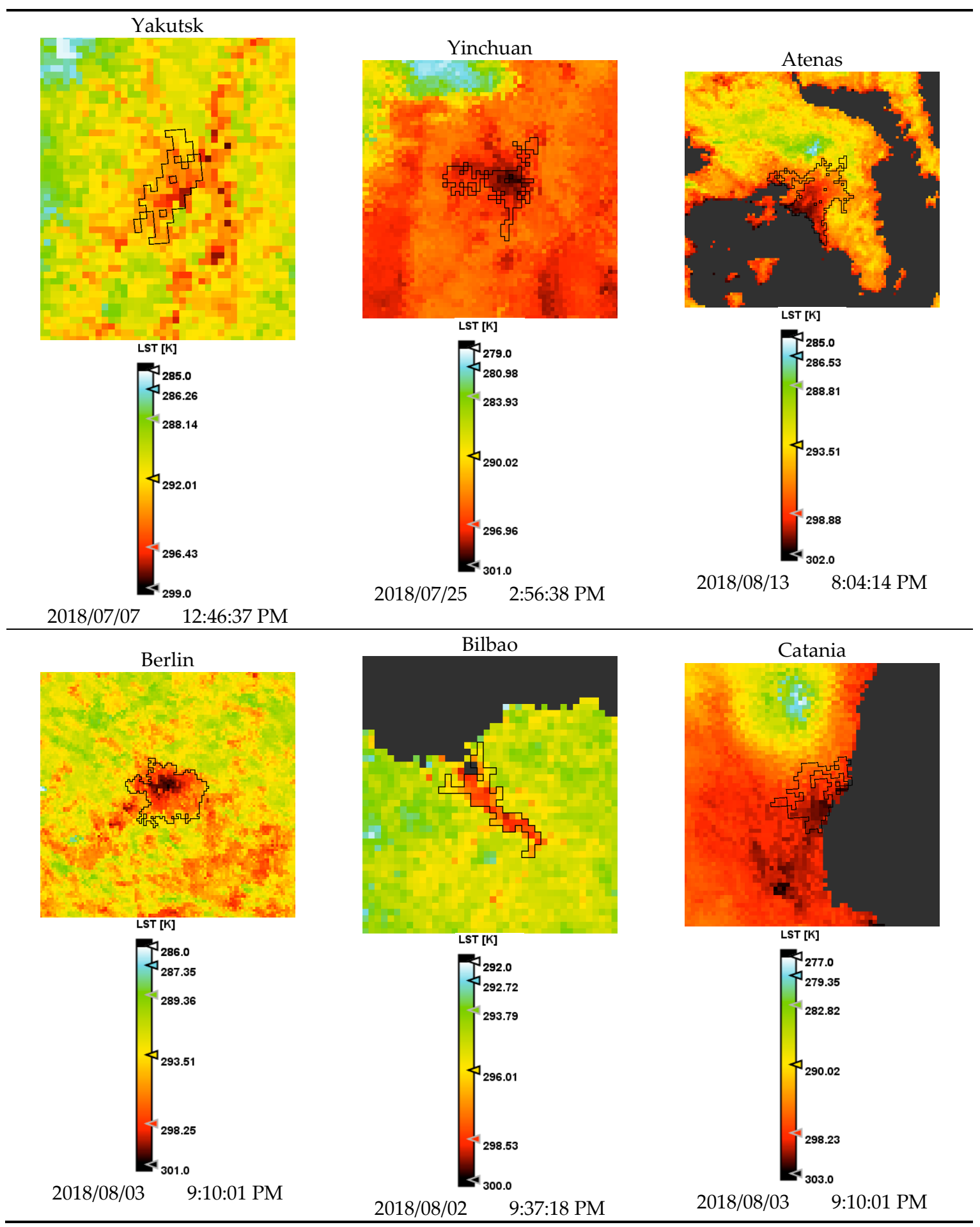

Figure A1. Cont. 


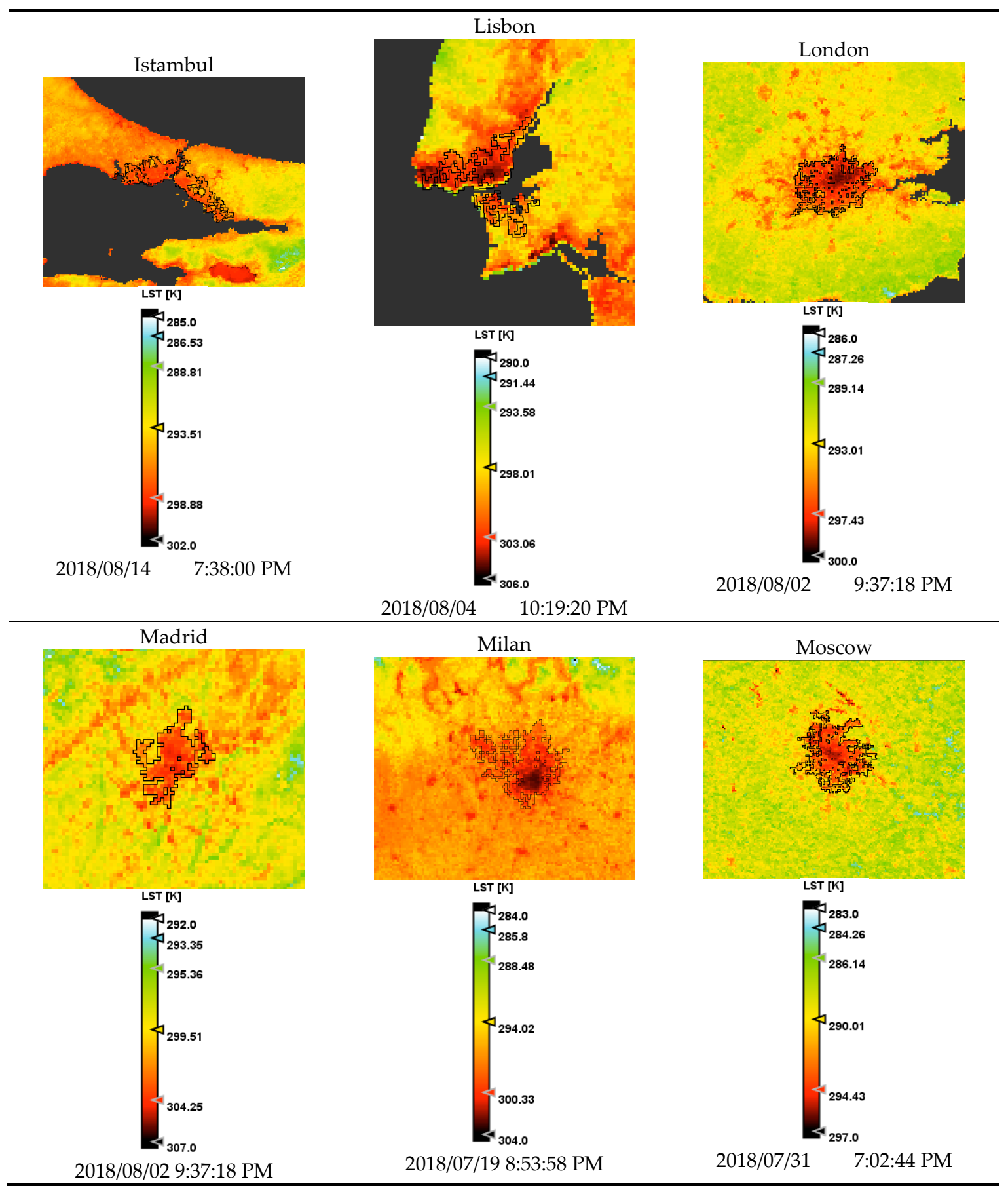

Figure A1. Cont. 


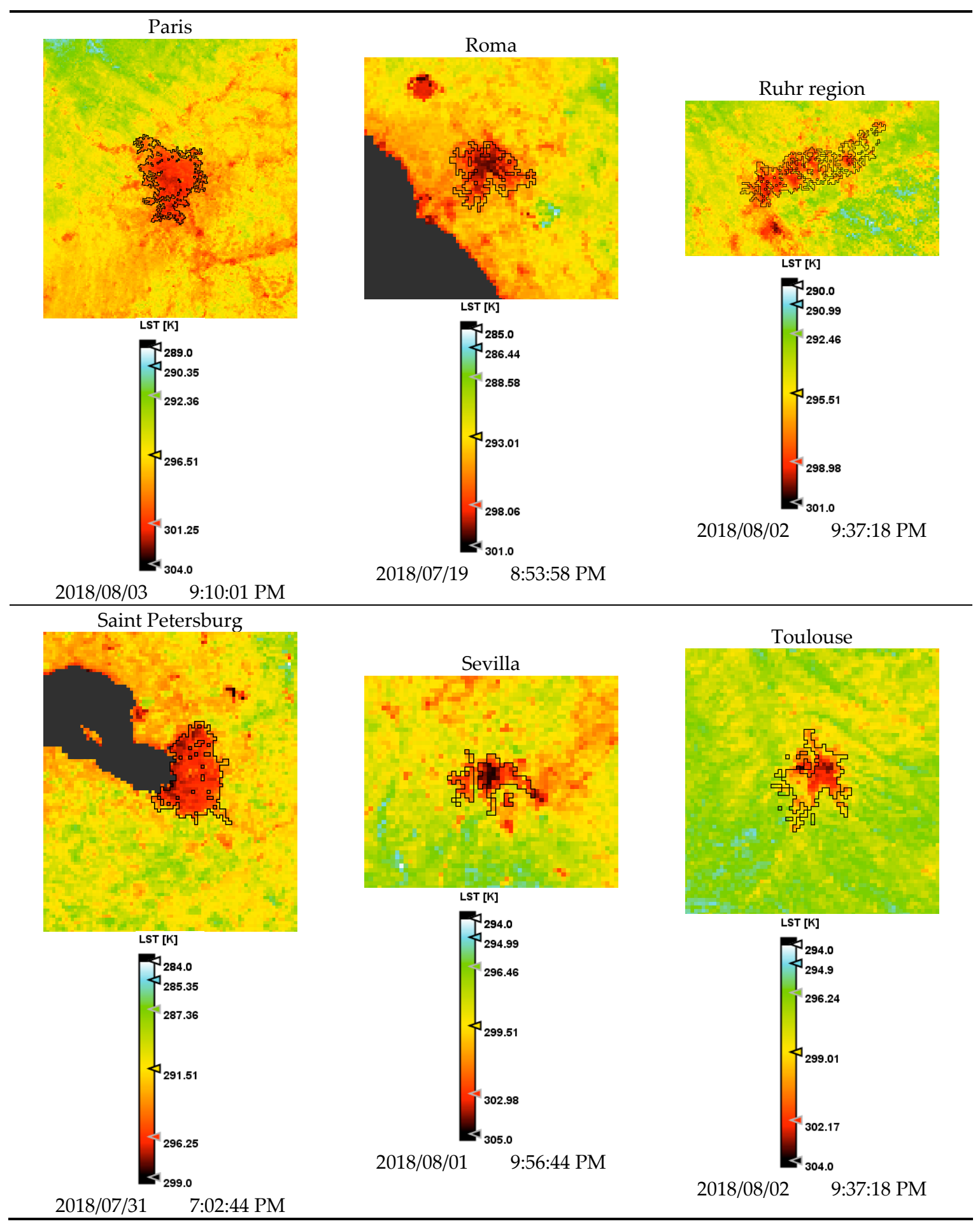

Figure A1. Cont. 

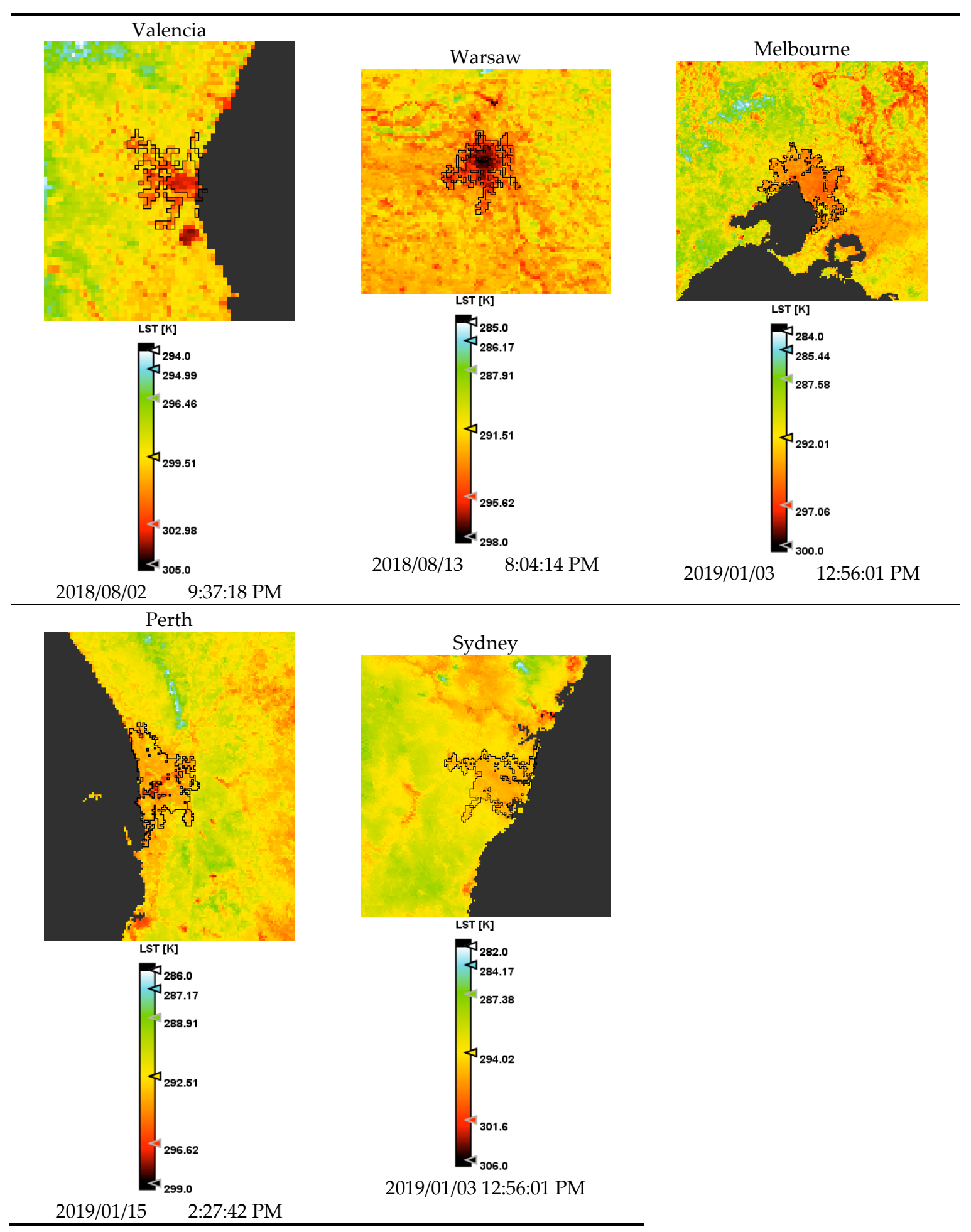

Figure A1. Land surface temperature images (Sentinel-3A SLSTR Level-2 LST product) of the urban agglomerations selected. The images cover the peri-urban area. The polygon is the urban area obtained from ESA CCI [33]. 


\section{References}

1. European Space Agency_ESA. Mapping our global human footprint. 2019. Available online: http: //www.esa.int/Our_Activities/Observing_the_Earth/Mapping_our_global_human_footprint (accessed on 10 July 2019).

2. Anbar, M. The Climate impact on human comfort in the eastern Nile Delta. J. Fac. Art Cairo Univ. 2012, 72, 267-319. (In Arabic)

3. Kim, H.H. Urban heat island. Int. J. Remote Sens. 1992, 13, 2319-2336. [CrossRef]

4. Streutker, D.R. A remote sensing study of the urban heat island of Houston, Texas. Int. J. Remote Sens. 2002, 23, 2595-2608. [CrossRef]

5. Sobrino, J.A.; Oltra-Carrió, R.; Sòria, G.; Jiménez-Muñoz, J.C.; Franch, B.; Hidalgo, V.; Mattar, C.; Julien, Y.; Cuenca, J.; Romaguera, M.; et al. Evaluation of the surface urban heat island effect in the city of Madrid by thermal remote sensing. Int. J. Remote Sens. 2012, 34, 3177-3192. [CrossRef]

6. Ahmed, S. Assessment of urban heat islands and impact of climate change on socioeconomic over Suez Governorate using remote sensing and GIS techniques. Egypt. J. Remote. Sens. Space Sci. 2018, 21, 15-25. [CrossRef]

7. Patz, J.A.; Campbell-Lendrum, D.; Holloway, T.; Foley, J.A. Impact of regional climate change on human health. Nature 2005, 438, 310-317. [CrossRef]

8. Santamouris, M.; Cartalis, C.; Synnefa, A.; Kolokotsa, D. On the impact of urban heat island and global warming on the power demand and electricity consumption of buildings-A review. Energy Build. 2015, 98, 119-124. [CrossRef]

9. O'Loughlin, J.; Witmer, F.D.W.; Linke, A.M.; Laing, A.; Gettelman, A.; Dudhia, J. Climate variability and conflict risk in East Africa, 1990-2009. Proc. Natl. Acad. Sci. USA 2012, 109, 18344-18349. [CrossRef] [PubMed]

10. Zhou, D.; Xiao, J.; Bonafoni, S.; Berger, C.; Deilami, K.; Zhou, Y.; Frolking, S.; Yao, R.; Qiao, Z.; Sobrino, J.A. Satellite Remote Sensing of Surface Urban Heat Islands: Progress, Challenges, and Perspectives. Remote Sens. 2018, 11, 48. [CrossRef]

11. Mavrogianni, A.; Davies, M.; Batty, M.; Belcher, S.; Bohnenstengel, S.; Carruthers, D.; Chalabi, Z.; Croxford, B.; Demanuele, C.; Evans, S.; et al. The comfort, energy and health implications of London's urban heat island. Build. Serv. Eng. Res. Technol. 2011, 32, 35-52. [CrossRef]

12. Sobrino, J.A.; Oltra-Carrió, R.; Soria, G.; Bianchi, R.; Paganini, M. Impact of spatial resolution and satellite overpass time on evaluation of the surface urban heat island effects. Remote Sens. Environ. 2012, 117, 50-56. [CrossRef]

13. Pal, S.; Ziaul, S. Detection of land use and land cover change and land surface temperature in English Bazar urban centre. Egypt. J. Remote Sens. Space Sci. 2017, 20, 125-145. [CrossRef]

14. Weng, Q.; Larson, R.C. Satellite Remote Sensing of Urban Heat Islands: Current Practice and Prospects. In Geo-Spatial Technologies in Urban Environments; Springer: Berlin/Heidelberg, Germany, 2005; pp. 91-111.

15. Pu, R.; Gong, P.; Michishita, R.; Sasagawa, T. Assessment of multi-resolution and multi-sensor data for urban surface temperature retrieval. Remote Sens. Environ. 2006, 104, 211-225. [CrossRef]

16. Giridharan, R.; Kolokotroni, M. Urban heat island characteristics in London during winter. Sol. Energy 2009, 83, 1668-1682. [CrossRef]

17. Bhatta, B. Analysis of Urban Growth and Sprawl from Remote Sensing Data; Springer: Berlin/Heidelberg, Germany, 2010.

18. Liu, L.; Zhang, Y. Urban Heat Island Analysis Using the Landsat TM Data and ASTER Data: A Case Study in Hong Kong. Remote Sens. 2011, 3, 1535-1552. [CrossRef]

19. Weng, Q. Remote sensing of impervious surfaces in the urban areas: Requirements, methods, and trends. Remote Sens. Environ. 2012, 117, 34-49. [CrossRef]

20. Xiong, Y.; Huang, S.; Chen, F.; Ye, H.; Wang, C.; Zhu, C. The Impacts of Rapid Urbanization on the Thermal Environment: A Remote Sensing Study of Guangzhou, South China. Remote Sens. 2012, 4, $2033-2056$. [CrossRef]

21. Abutaleb, K.; Ngie, A.; Darwish, A.; Ahmed, M.; Arafat, S. Assessment of Urban Heat Island Using Remotely Sensed Imagery over Greater Cairo, Egypt. Adv. Remote Sens. 2015, 4, 35-47. [CrossRef] 
22. Li, X.; Li, W.; Middel, A.; Harlan, S.; Brazel, A.; Turner, B. Remote sensing of the surface urban heat island and land architecture in Phoenix, Arizona: Combined effects of land composition and configuration and cadastral-demographic-economic factors. Remote Sens. Environ. 2016, 174, 233-243. [CrossRef]

23. Zhou, D.; Zhao, S.; Liu, S.; Zhang, L.; Zhu, C. Surface urban heat island in China's 32 major cities: Spatial patterns and drivers. Remote. Sens. Environ. 2014, 152, 51-61. [CrossRef]

24. Khandelwal, S.; Goyal, R.; Kaul, N.; Mathew, A. Assessment of land surface temperature variation due to change in elevation of area surrounding Jaipur, India. Egypt. J. Remote Sens. Space Sci. 2018, 21, 87-94. [CrossRef]

25. Al Kuwary, N.Y.; Ahmed, S.; Kaiser, M.F. Optimal Satellite Sensor Selection Utilized to Monitor the Impact of Urban Sprawl on the Thermal Environment in Doha City, Qatar. J. Earth Sci. Clim. Chang. 2015, 7, 1. [CrossRef]

26. Voogt, J.A.; Oke, T. Thermal remote sensing of urban climates. Remote. Sens. Environ. 2003, 86, 370-384. [CrossRef]

27. Chen, X.; Zhao, H.-M.; Li, P.-X.; Yin, Z.-Y. Remote sensing image-based analysis of the relationship between urban heat island and land use/cover changes. Remote Sens. Environ. 2006, 104, 133-146. [CrossRef]

28. Zhou, D.; Bonafoni, S.; Zhang, L.; Wang, R. Remote sensing of the urban heat island effect in a highly populated urban agglomeration area in East China. Sci. Total Environ. 2018, 415-429. [CrossRef]

29. European Space Agency. Sentinel 3 SLSTR Level-2 LST. Available online: https://earth.esa.int/web/sentinel/ technical-guides/sentinel-3-slstr/level-2-algorithms-products (accessed on 16 January 2020).

30. Zhang, Y. Land surface temperature retrieval from CBERS-02 IRMSS thermal infrared data and its applications in quantitative analysis of urban heat island effect. J. Remote Sens. 2006, 10, 789-797.

31. Toy, S.; Yılmaz, S.; Yilmaz, H. Determination of bioclimatic comfort in three different land uses in the city of Erzurum, Turkey. Build. Environ. 2007, 42, 1315-1318. [CrossRef]

32. Stewart, I.D.; Oke, T.R. Local Climate Zones for Urban Temperature Studies. Bull. Am. Meteorol. Soc. 2012, 93, 1879-1900. [CrossRef]

33. European Space Agency-ESA. Climate Change Initiative Land Cover 2015. Available online: https: //maps.elie.ucl.ac.be/CCI/viewer/ (accessed on 16 January 2020).

34. Kasanko, M.; Barredo, J.I.; LaValle, C.; McCormick, N.; Demicheli, L.; Sagris, V.; Brezger, A. Are European cities becoming dispersed? Landsc. Urban Plan. 2006, 77, 111-130. [CrossRef]

35. García-Nieto, A.P.; Geijzendorffer, I.R.; Baró, F.; Roche, P.; Bondeau, A.; Cramer, W. Impacts of urbanization around Mediterranean cities: Changes in ecosystem service supply. Ecol. Indic. 2018, 91, 589-606. [CrossRef]

36. Giles, B.D.; Balafoutis, C.; Maheras, P. Too hot for comfort: The heatwaves in Greece in 1987 and 1988. Int. J. Biometeorol. 1990, 34, 98-104. [CrossRef]

37. Thom, E.C. The Discomfort Index. Weatherwise 1959, 12, 57-61. [CrossRef]

38. Atmospheric Infrared Sounder (AIRS L3 Product) on Board NASA's AQUA Satellite. Available online: https://worldview.earthdata.nasa.gov/?p=geographic\&l=MODIS_Terra_CorrectedReflectance_ TrueColor,AIRS_L3_Surface_Relative_Humidity_Daily_Night (accessed on 10 January 2020).

39. UN; United Nations Department of Economic Social Affairs Population Division. World Urbanization Prospects: The 2018 Revision; United Nations: New York, NY, USA, 2018.

40. Seto, K.C.; Güneralp, B.; Hutyra, L.R. Global forecasts of urban expansion to 2030 and direct impacts on biodiversity and carbon pools. Proc. Natl. Acad. Sci. USA 2012, 109, 16083-16088. [CrossRef] [PubMed]

41. Field, C.B.; Barros, V.R.; Dokken, D.J.; Mach, K.J.; Mastrandrea, M.D. Climate Change 2014-Impacts, Adaptation and Vulnerability: Part A: Global and Sectoral Aspects by Intergovernmental Panel on Climate Change; Cambridge University Press: Cambridge, UK, 2014.

42. European Space Agency-ESA. Nitrogen dioxide worldwide. 2019. Available online: https://www.esa.int/ spaceinimages/Images/2019/03/Nitrogen_dioxide_worldwide (accessed on 16 May 2020).

43. ESA Sentinel-3 Data Product Quality Reports. Available online: https://earth.esa.int/web/sentinel/technicalguides/sentinel-3-slstr/data-quality-reports (accessed on 25 February 2020).

44. Sobrino, J.A.; Julien, Y.; García-Monteiro, S. Surface Temperature of the Planet Earth from Satellite Data. Remote Sens. 2020, 12, 218. [CrossRef] 
45. Kottek, M.; Grieser, J.; Beck, C.; Rudolf, B.; Rubel, F. World Map of the Köppen-Geiger climate classification updated. Meteorologische Zeitschrift 2006, 15, 259-263. [CrossRef]

46. United Nations, Department of Economic and Social Affairs, Population Division, United Nations. The World's Cities in 2018-Data Booklet 2018 (ST/ESA/ SER.A/417). Available online: https://www.un.org/en/development/desa/population/publications/pdf/urbanization/the_worlds_ cities_in_2018_data_booklet.pdf (accessed on 10 January 2020).

(C) 2020 by the authors. Licensee MDPI, Basel, Switzerland. This article is an open access article distributed under the terms and conditions of the Creative Commons Attribution (CC BY) license (http://creativecommons.org/licenses/by/4.0/). 